\title{
TÜRK VATANDAŞLIĞI KANUNU'NDA DEĞİŞIKLİK YAPAN 2003 TARİHLİ ve 4866 SAYILI KANUN KAPSAMINDA BİR DEĞERLENDİRME
}

\author{
Doç. Dr. Fügen SARGIN*
}

\section{GíRiş}

22 Mayıs 1964 tarihinde yürürlüğe giren 403 sayılı Türk Vatandaşlı̆̆ Kanunu (TVK.) ${ }^{1}$, çeşitli tarihlerde, bazı hükümleri itibariyle değişikliğe uğramıştır. Ancak, döneme egemen olan politik, sosyal etkiler nedeniyle gereksinim duyulan bu değişiklikler, Kanun'un orijinal metninin sistematik ve Türk Vatandaşlığı Hukukuna hâkim olan genel ilkeler dahilinde mantıksal bütünlüğünü ortadan kaldıran bir yaklaşım içinde, maddeleri gelişigüzel kaleme alınmış bir Kanun görüntüsü yaratmıştır. Nitekim, bu doğrultuda son bir değişiklik de, 04 Haziran 2003 tarihli ve 4866 sayılı "Türk Vatandaşlı̆̆ 1 Kanunu'nda Değişiklik Yapılmasına İlişkin Kanun” ile ${ }^{2}$ gerçekleştirilmiş ve içerdiği hükümler, Türk Vatandaşlığı Kanunu'nu adeta birbiriyle uyumsuz kurallar yumağ haline getirmiştir.

Anayasa'nın çizdiği genel çerçeve içinde, Kanun'da öngörülen sebeplerin ve vatandaşlık hukukî statüsünün süjesi olacak bireylerin belirlenmesi sürecinde esas alınan politik, sosyal nedenler dahilinde, değiştirilen Kanun hükümlerinin yerindeliğinin değerlendirilmesi hususu bir yana bırakılacak olursa, yapılan son değişiklikle, mevcut Kanun'da meydana getirilen karmaşanın hiç değilse kendi içindeki sistematik ve mantıksal bütünlügüunü sağlayacak ölçüde giderilmesi bağlamında, Kanun'un diğer

\footnotetext{
* Ankara Üniversitesi Hukuk Fakültesi Uluslararası Özel Hukuk Anabilim Dalı Öğretim Üyesi.

${ }^{1}$ RG. 22 Şubat 1964, S. 11638; “Bu Kanun yayımından üç ay sonra yürürlüğe girer" hükmünü içeren 47. maddesi uyarınca, 403 sayılı Kanun, 22 Mayıs 1964'de mer'iyet kazanmış bulunmaktadır.

${ }^{2}$ RG. 12 Haziran 2003, S. 25136; http://hbs/BAHUM/scripts/ Body.asp? Mevzuat ID=91817 \& MaddeID = 658481; Kanun'un 7. maddesi uyarınca, Kanun yayımı tarihinde yürürlüğe girmiştir.
} 
bazı hükümlerinin de yeniden gözden geçirilmesi/değiştirilmesi gerekli hale gelmiştir.

1964 tarihli Kanun'un ortaya çıkan bu tutarsız görüntüsü, kanun koyucunun, tamamına hâkim olan genel düşünce ve tercih dahilinde Kanun hükümlerini bütünüyle ele almaması ve sanki diğer hükümlerin getiriliş amacından bağımsızmışcasına, birbiriyle bağlantılı madde hükümlerini göz ardı ederek, münferit değişiklikler yapmasından kaynaklanmaktadır.

Esasen, günümüz itibariyle, 1964 tarihli ve 403 sayılı Türk Vatandaşlığı Kanunu'nun tümüyle gözden geçirilerek; yeni bir kanun hazırlanması gerekli hale gelmiş bulunmaktadır. ${ }^{3}$ Ancak, bu çalışmamızda, geçmiş yıllarda gerçekleştirilen kanun değişikliklerinin Kanun'un bütünü ile yarattığ 1 diğer uyumsuzluklar irdelenmeyecektir. Milletlerarası Hukukun çizdiği sınırlar dahilinde sahip olunan düzenleme serbestisi içinde, özellikle insan haklarını düzenleyen temel metinlerde Vatandaşlık Hukukuna yön verecek ilkelerle ${ }^{4}$

\footnotetext{
${ }^{3}$ Nitekim İçişleri Bakanlığ Nüfus ve Vatandaşlık İşleri Genel Müdürlüğü, 03 Kasım 2003 tarihli ve B050NÜV0070003.145.29399 sayılı yazısıyla, mevcut Kanun’un bütünüyle değiştirilmesi amacıyla bir çalışmanın başlatılmış olduğunu, “ . ....Türk Vatandaşlığı Kanunu 1981 yılında genel bir düzenlemeye tâbi tutulmuş ve bu tarihten sonra küçük değişiklikler dışında ele alınmamıştır. Yaklaşık 40 yıldan beri yürürlükte bulunan bu Kanun'un günün ihtiyaç ve koşulları ile dünyada yaşanan gelişmeler karşısında yeniden ele alınması zorunlu hale gelmiştir", ifadesi ile belirtmiş bulunmaktadır. Ancak, aynı yazıda, "Türk vatandaşlı̆̆ının kazanılması ve kaybedilmesine ilişkin yapılacak olan yeni düzenlemelere $1 s ̧ ı$ tutmak amacıyla, Avrupa Birliği ülkeleri vatandaşlık mevzuatının da göz önünde bulundurulması suretiyle" "mevcut TVK. hükümleri hakkında görüş ve öneri bildirilmesi"nden söz edilmektedir. Oysa, bu tür bir yaklaşımla TVK.'nun, AB. üyesi ülkelerin Vatandaşlık Hukukuyla uyumlaştırılması düşüncesi uygun olmayacaktır. Zira, Milletlerarası Hukukta, milletlerarası sözleşme ve mahkeme kararlarına da yansıdığı şekilde, bu konuda her devletin münhasır yetkisi vardır ve tâbiiyet bağı ile bağlanacak bireylerin tespiti, devletin, devletsel menfaatleri çerçevesinde yapılacaktır. Dolayısıyla örneğin, dişa göçün yoğun olarak yaşandığı bir ülkenin devletsel menfaati ile, içe göçün yoğun yaşandığı bir ülkenin menfaatlerini aynı potada eritmek mümkün değildir. Doğal olarak, Vatandaşlık Hukuku düzenlemeleri, devletsel menfaatleri dahilinde farklılık arzeden AB. üyesi ülkelerle uyum sağlama çabası, temelde esas alınan ve insan hakları kavramını da yansıtan milletlerarası hukuk kuralları dışında, anlamsız olacaktır. Devletlerin vatandaşlarını tayin noktasında sahip olduğu münhasır yetkiyi yansıtan ve 1 Mart 2000'de yürürlüğe giren Avrupa Konseyi Vatandaşlık Sözleşmesi "European Convention on Nationality"in 3. maddesi için bikz. Rona AYBAY: Vatandaşlık Hukuku, B. 5, İstanbul 2003, sh. 339; Vatandaşlık Çatışmalarınm Önlenmesine Dair Sözleşme'nin 1 ve 2. md. için bkz. Aslan GÜNDÜZ: Milletlerarası Hukuk Metinleri, B. 4, İstanbul 2000, sh. 562.

${ }^{4}$ Nitekim, Türkiye'nin tarafı olduğu, 3 Eylül 1981 tarihinde yürürlüğe giren "Kadınlara Karşı Her Türlü Ayrımcılığın Önlenmesine Dair Sözleşme”( 24 Temmuz 1985 tarihli ve 85/9722 sayılı Bakanlar Kurulu Kararı: RG. 14 Ekim 1985, S. 18898); temel insan haklarını düzenleyen "Birleşmiş Milletler Medenî ve Siyasî Haklara İlişkin Uluslararası Sözleşme (04 Haziran 2003 tarihli ve 4868 sayılı Kanun ile onaylanması uygun bulunan Sözleşme'nin metni: http://rega.basbakanlik.gov.tr/Eskiler/2003/07/20030721.htm, (05 Aralık 2003
} 
tarafı olunması düşünülen ${ }^{5}$ uluslararası sözleşme hükümleri de dikkate alınarak, yeniden çerçevesi belirlenebilecek Kanun'un bütününe yönelik somut bir değişiklik önerisinde bulunulmayacaktır. İçeriği, Kanun'da 4866 sayılı Kanun ile yapılan değişiklikliğin değerlendirilmesiyle sınırlı olacaktır.

4866 sayılı Kanun ile, 403 sayılı Kanun'un evlenme suretiyle vatandaşlık kazanımını ve usûlünü düzenleyen 5., 42. maddeleri; yetkili makam kararı ile yeniden vatandaşlık kazanımına dair 8. maddesi; Türk vatandaşlığından yetkili makam kararı ile çıkmayı ve onun sonuçlarını düzenleyen 20., 29., 32. maddeleri değiştirilmiş bulunmaktadır. Bu maddeler, sirasiyla ele alınacaktır.

\section{EVLENME SURETIYLE TÜRK VATANDAŞLIĞININ KAZANILMASI}

\section{Eşler Bakımından Evlenmenin Vatandaşlığa Etkisi}

4866 sayılı Kanun'un 1. maddesiyle, 403 sayılı Kanun'un 5. maddesinde yapılan en önemli değişiklik, bu yolla Türk vatandaşlığının kazanımı imkânının, yabancı kadınların yanı sıra erkeklere de tanınmış ve süreye bağlanmış olmasıdır. Yeni maddeye göre, kural, bir Türk vatandaşı ile evlenmenin kanun hükmü gereği kendiliğinden vatandaşlık bahşetmeyeceğidir. Ancak, bir Türk vatandaşı ile evli olan yabancılar, kadın/ erkek ayrımı yapılmaksızın, en az üç yıldan beri evli olmak, fiilen birlikte

tarihi itibariyle)); "Avrupa İnsan Haklan Sözleşmesi, (Avrupa İnsan Hakları Sözleşmesi, Ankara 1998, Turhan Kitabevi Yayınları, sh. 4 vd.) insan haklarını düzenleyen temel metinlere örnek gösterilebilir. Bu çerçevede, Birleşmiş Milletler Medenî ve Siyasî Haklara İlişkin Uluslararası Sözleşme'nin 24. maddesine göre, "her çocuğun bir vatandaşlık kazanma hakkı vardır”; Kadınlara Karşı Her Türlü Ayrımcılığın Önlenmesine Dair Sözleşme'nin 9/1. maddesi gereğince, "Taraf devletler tâbiiyetin kazanılmasında, değiştirilmesinde veya muhafazasında kadınlara, erkeklerle eşit haklar tanıyacaklar ve özellikle bir yabancı ile evlenmenin veya evlilik sırasında kocanın tâbiiyetini değiştirmesinin, kadının da otomatik olarak tâbiiyet değiştirmesine, tâbiiyetsiz kalmasına veya kocanın tâbiiyetini zorla almasına yol açmamasını temin edeceklerdir". Yine, aynı maddenin 2. fıkrasına göre, "Taraf devletler, çocukların tâbiiyeti konusunda, kadınlara erkeklerle eşit haklar sağlayacaklardır".

${ }_{5}^{5}$ Avrupa Konseyi Vatandaşlık Sözleşmesi "European Convention on Nationality"nin 7 maddesiyle, bireyin iradesi dışında vatandaşlığına son verilmesi, vatandaşlığın, talepte bulunanın hileli davranışları, yalan beyanda bulunması veya ilgili hususları gizlemiş olması nedenlerine dayalı olarak kazanımı hali hariç, bireyin vatansız kalması sonucunu doğuracak ise, mümkün olmayacak; üye devletler bu yönde millî hukuklarına hüküm koyamayacaklardır. Ancak, Sözleşme'nin 29. maddesinde belirtildiği üzere, üye devletlerin bu maddeye, Sözleşme'nin amacıyla uyumlu olmak kaydıyla, çekince koyma hakları da bulunmaktadır. Sözleşme'ye Türkiye üye olduğu takdirde, söz konusu çekince hakkını kullanmazsa, 7. madde hükmü nedeniyle, TVK. md. 22 / III.fik. md. 25 ve md. 26 maddeye göre Türk vatandaşlığının kaybı, yeniden düzenlenmek durumunda kalınacaktır. TBMM.'de TVK. değişikliklerinin görüşülmesi sırasında, bu Sözleşme'nin imzalanmasının düşünüldüğünün zikredildiği hakkında bkz. AYBAY, age., sh. 5 ve sh. 337. 
yaşamak ve evliliğin devamı kaydı ile, vatandaşlığa alınma başvurusunda bulunabileceklerdir (1. fik.). Bununla birlikte, sözü edilen süre ve başvuru şartı, Türk vatandaşı ile evlenmeleri nedeniyle eski vatandaşlığını kaybederek vatansız hale gelecek yabancılar bakımından aranmayacaktır ( 2 . fik).

Vatandaşlığa alınma için süre öngörülmüş olması, sadece vatandaşlık elde etmeye yönelik muvazaalı evliliklere, vatandaşlık kazanımı hukukî sonucunu bağlamaktan kaçınmak amacıyladır. ${ }^{6} 3$ yıl süre ile fiilen birlikte yaşamak ve devam eden bir evlilik kayd, bireylerin evlenme iradesinin gerçek anlamda evlenme niyeti ile beyan edildiğini ${ }^{7}$; vatandaşlık kazanımının ise, evlenme hukukî işlemine, belirli şartlarla bağlanmış hukukî bir sonuç olduğunu ortaya koymak bakımından yerinde olmuştur.

Bununla birlikte, evlenmenin vatandaşlığa etkisinin, kanun hükmü gereği kazanma başlığı altında değil de, diğer bazı hukuk sistemlerinde olduğu gibi, yetkili makam kararı ile vatandaşlığın kazanımı hallerinden biri olarak, vatandaşlık kazanma nedenleri arasında düzenlenmesi daha uygun olurdu. Bu hukuk sistemlerinde, vatandaş ile evlenme, telsik bakımından aranan, müktesep bir kazanma hali yarattığı için, devlet ile olması gereken ilgi bağını ortaya koyan ve vatandaşlığa alınmayı kolaylaştıran unsurlardan biri olarak görülmektedir. ${ }^{8}$ Bu açıdan bakıldığında, belli bir süre evliliğin

\footnotetext{
${ }^{6}$ İ̧̧işleri Bakanlığı'nca hazırlanan ve 21. Dönem TBMM. Başkanlığı'na sunulan Tasarı'nın gerekçesinde, mevcut 5. maddenin, hem "kadın/erkek eşitsizliğine neden olduğu", hem de "evlilik kurumunun yozlaşmasına ve Türk vatandaşı olabilmek için sahte evlilikler yapılmasına yol açtı̆̆ı"; bu nedenle maddenin değiştirilmesinin zorunlu hale geldiği ifade edilmiş bulunmaktadır. TBMM.'ne sunulan, Türk Vatandaşlığı Kanunu'nda Değişiklik Yapılmasına İlişkin Kanun Tasarısı"na dair gerekçe için bkz.: Başbakanlık Kanunlar ve Kararlar Müdürlüğü, 01 Mart 2002 tarihli ve B.02.0.KKG.0.10/101-411/1087 sayılı yazı; İlgili Tasarı, adı geçen dönemde sonuçlandırılamadığından hükümsüz sayılmış ve 13 Ocak 2003 tarihinde, Bakanlar Kurulu'nca TBMM.'ye sunulmuştur. TBMM. Başkanlığı tarafından İçişleri Komisyonu'na havale edilen tasarı görüşülmüş ve bu toplantıda, aynı gerekçeler tekrarlanmıştır. Bkz. T. 03 Mart 2003, E. 1/482, K. 29, TBMM. İçişleri Komisyonu Raporu: http: // www. tbmm. gov . tr / sirasayi / donem22/yil01/ss115m.htm (19 Aralık 2003 itibariyle).

${ }^{7}$ İçişleri Komisyonu Raporu'nda, 5. madde değişikliği ile, evlilik kurumunun saygınlığının korunmaya çalışıldığı ifade edilmektedir. Metinde belirtildiği üzere, "Ülkemize giren yabancılar, yasa dışı ilişkilere girmekte; toplum ahlâkı ve sağlığı ile aile düzenini bozmaktadırlar. Bu kişiler, Ülkemizde daha rahat hareket edebilmek; yasadişı faaliyetlerini vatandaşlara sunulan hakları da kullanarak sürdürebilmek için muvazaalı evlilikler yapmakta ve vatandaşlığı kazandıktan sonra boşanmaktadırlar. .....Böylece, Türk vatandaşlığı, hak ettiği saygın statüye kavuşturulmakta; evlilik kurumunun kötüye kullanılmasının önüne geçilmektedir." Bkz. http: // www. tbmm. gov . tr / sirasayi / donem22/yil01/ss115m.htm (19 Arallk 2003 itibariyle).

${ }^{8}$ Alman Vatandaşlık Hukuku, Alman vatandaşlarının yabancı eşlerinin, bu evlililik nedeniyle Alman vatandaşlığını telsik yoluyla " naturalization" kazanmasını, diğer telsik yoluyla
} 
devam etmiş ve başvuru tarihinde halen devam etmekte olması yeterli sayılmamakta; bunun yanı sıra, ayrıca bu ilgi bağını daha da yoğunlaştıracak biçimde, vatandaşlığı kazanılacak ülkede bu sürenin önemli bir bölümünün geçirilmiş olması şartı da aranmaktadır. Ancak, bu süre, diğer nedenlerle yetkili makam kararıyla vatandaşlık kazanımına nazaran daha kısa belirlenmektedir.' Oysa, Türk Hukukundaki bu düzenleme, sadece gerçek evlenme niyetini tespite yarayan, ama vatandaşlı̆̆ın kazanımını sağlayacak ölçüde Türkiye ile olan ilgi bağının varlığını, diğer yabancılara nazaran daha da yoğunlaştıran içerikte bir karine yaratmamaktadır. Bu nedenle, muhtemel bir değişiklikte, kural olarak birlikte belirli bir süre, Türkiye'de fiilen ikamet etme şartına da yer verilmesi düşünülmelidir. ${ }^{10}$ Bununla birlikte, çok sayıda Türk vatandaşının ülke dışında yaşıyor / çalışıyor olması gerçeği karşısında, onunla birlikte yabancı ülkede ikamet etmek durumunda kalan yabancı eşler bakımından, Türkiye ile ilgi bağını gösteren başka bir nedene dayalı yakın

vatandaşlık kazanabilecek kişi gruplarından farklı şartlara tâbi kılmaktadır: Bkz. Rainer HOFFMANN: "German Citizenship Law and European Citizenship: Towards a Special Kind of Dual Nationality" in European Citizenship (Ed. by Massimo La TORRE), The Hague/London/Boston, 1998, sh. 150; İngiliz Vatandaşlık Hukukunda da, 1981 tarihli The British Nationality Act, evlenme suretiyle vatandaşlık kazanımını "telsik" başlı̆̆ı altında düzenlemektedir. Kanunda öngörülen tüm şartların gerçekleşmesi üzerine yetkili makam, Dışişleri Bakanlığı'na“Secretary of State”, bireyin vatandaşlığa alınmasının uygun olup olmadığı noktasında nihaî olarak takdir yetkisi tanınmaktadır. Telsik için başvuru tarihinde bir İngiliz vatandaşı ile evli olan eş bakımından, tek fark, telsik için öngörülen genel şartlardan bazılarının aranmayacak olmasıdır.Bu bilgi için bkz. Profile of British Nationality Law-UK Immigration-News and Information: http:/www.gherson.com/news.php3? article=nationality, (04 Aralık 2003 tarihi itibariyle); Yine, Avrupa Vatandaşlık Sözleşmesi'nin 6/4. maddesine göre, her devlet, kendi iç hukukunda tebaasının eşlerinin tâbiiyet kazanmasını "kolaylaştıracak" düzenlemeleri yapmak mükellefiyeti altındadır.

${ }^{9}$ Nitekim ABD. Hukukunda, Immigration and Nationality Act Title III, telsik yolu ile vatandaşlığın kazanımı "nationality through naturalization" başlığını taşıyan Chapter 2'de yer alan md. 319'da, bireyin md. 310 ile belirlenen yetkili makam kararı ile ABD. vatandaşlığını kazanması için, başvuru sırasında halen ABD. vatandaşlığını koruyan eş ile evlilik birliğini sürdürüyor olması ve hukuka uygun biçimde $\mathrm{ABD}$.' de sürekli oturmasına izin verildiği tarihten itibaren en az 3 yıldan beri sürekli biçimde ABD.'de ikamet ediyor bulunması şarttır. Ayrıca toplam sürenin en azından yarısını fizikî olarak ABD.'de geçirmesi ve başvuruda bulunduğu Eyalet ya da ABD. "Service District"de en aşağı 3 aydan beri oturuyor olması da aranmaktadır. 319. maddede belirlenen bazı organizasyonlarda yurtdışında çalışan ABD. vatandaşlarının eşleri, ikamet şartından da muaf tutulmaktadır (md. 319/(b) ). Bu özel hüküm ile, genel olarak telsik yoluyla vatandaşlığa alınma başvurusunda bulunan diğer kişilere nazaran kolaylaştırıcı şartlar belirlenmiş bulunmaktadır. Bununla birlikte, ilgili kolaylaştınıcı hükümler dışında, genel olarak telsik için aranan diğer şartları, 316(a)/1. paragraf hükmü istisna edilmek üzere, yerine getirmek zorundadırlar: Kanun için bkz. http:// www. immigration-usa. com / ina _ 96 _ title_3.html (12 Aralık 2003 tarihi itibariyle).

${ }^{10}$ Yapılan bu öneri, evlenme suretiyle Türk vatandaşlığının kazanımının, "seçme hakkı" içinde değerlendirilmesi ile mümkündür. Telsik içinde düzenlendiği takdirde, TVK. md. 7 'nin ikamet şartı aramayan mevcut hükmü ile bağdaşmayacaktır. 
bir ilişkinin de varlı̆̆ı kaydına bağlı olarak, 3 yıldan daha uzun bir süre evlilik birliğinin devamı şartının aranması ${ }^{11}$; yabancı ülkede Türkiye'yi temsilen görev yapan Türk vatandaşlarının, bu nedenle ülkede birlikte ikamet etmeleri mümkün olmayan yabancı eşlerin ${ }^{12}$, Türkiye'de ikamet etme şartı aranmamak kaydıyla Türk vatandaşlığını kazanmalarını sağlamak düşünceleri de birer öneri olarak, göz önüne alınabilir.

Öte yandan, "bu düzenleme tarzı" ile, 5. maddenin, Kanun'un Birinci Bölüm'ünün "I. Kanun yolu ile kazanma" başlığı altında yer almaması da gerekirdi.

Doktrinde, bir görüş, "Kanun'daki bu değişiklikten sonra, TVK. md. 5'i, eskiden olduğu gibi seçme hakkı başlığ olmayacağını; TVK. md. 5'e, Kanun'un 6-11. maddelerini kapsayan, "yetkili makam kararı ile kazanma" alt başlığı altında yer verilmesinin daha uygun bulunacağın”" belirtmektedir. Görüşe göre, "TVK.'nun değişik biçimi, Türkle evlenen yabancıya, başvurusu halinde, yetkili makamın değerlendirmesine ve takdirine göre vatandaşlık verilmesini düzenlemektedir. ....Yani, telsik için iki temel koşul olan, ilgilinin ...başvuruda bulunması ve yetkili makamın başvuruyu koşullara uygunluk bakımından değerlendirip, takdirine göre sonuçlandırması, burada da aynen vardır". ${ }^{13}$

Kanımızca, TVK. md. 5 'in, şu anki düzenleniş tarzı itibariyle, Birinci Bölüm'deki "II. Yetkili Makam Kararı ile Kazanma" başlı̆̆ı altında değil de, "III. Seçme Hakkı ile Kazanma" başlığı altında yer alması gerekirdi. Maddenin gerekçesinde, “...bir Türk vatandaşı ile evli yabancı erkek veya kadın; ciddi bir evlilik yapmışlarsa, en az 3 yıldır evlilerse ve evlilik halen devam ediyorsa, güvenlik açısından yapılan inceleme ve araştırma sonucunda da vatandaşlı̆̆a geçmelerinde herhangi bir sakıncalarının bulunmadığ 1 tespit edilmişse, başvurdukları takdirde, vatandaş

\footnotetext{
${ }^{11}$ Isviçre Hukuku için bkz. Vahit DOĞAN: “ Vatandaşlık Kanununun Bazı Maddelerinin Değiştirilmesine İlişkin Kanun Tasarısı Çerçevesinde Bir Değerlendirme”, Gazi Üniversitesi Hukuk Fakültesi Dergisi, 1999, C. III, S.1-2, sh. 29-30'da yer alan Dn. (10).

${ }^{12}$ ABD. Hukukunda yer alan düzenleme için bkz. yuk. Dn. (9).

${ }^{13}$ Bu yönde bkz. AYBAY, age., sh. 96; Rona AYBAY: “ Türk Vatandaşlığı Kanunu'nda Geri Gidiş Getiren Değişiklik”, Açı Sayfa, 2003, S. 45-46, sh. 20; Bu görüşe göre, "TVK. md. 5 gere ğince Türk vatandaşlığını kazanacak yabancının sahip olduğu vatandaşlığına son vermesi koşulunun da aranmaması, TVK.'nun, telsiki çifte vatandaşlığı bir sakınca olarak görmeyen tutumuna uygundur”. Oysa, kanımızca, TVK. md. 5 'deki düzenlemeyi telsik olarak nitelendiren düşünce dahilinde, TVK.'nun 10. maddesi, şartlı vatandaşlık kazanımını devreye sokacaktır. Dolayısıyla, mevcut vatandaşlığın terk edilmesi şartı, evlenme suretiyle Türk vatandaşlığını kazanacak kişiler bakımından da aranabilecektir. Zira, ilgili madde, yetkili makama, Kanun'da sayılan şartlara ek bir şartı belirleme konusunda, takdir yetkisi tanımış bulunmaktadır ve TVK. md. 5 yetkili makam kararı ile Türk vatandaşlığına alınma biçimi olarak nitelendirilirse, 10 . maddedeki takdirî yetki 5 . maddeyi de kapsamına alacaktır.
} 
olabileceklerdir" ifadesine yer verilmiş bulunmaktadır. Gerekçe'deki ifadeye göre, evlenme suretiyle vatandaşlığın kazanımı, 3 yıldır evli olma, evliliğin devamı ve güvenlik soruşturması sonucunda sakıncalı bulunmama hukukî sebeplerine bağlanmış olmaktadır. O halde, "güvenlik açısından sakıncalı bulunmama" vatandaşlığa alınma şartlarından biri olarak Gerekçe'de yer almaktadir.

Oysa, her şeyden önce, değişik 5. madde metnine göre, vatandaşlığa alınma şartları, "en az 3 yıldır evli olmak", "fiilen birlikte yaşamak ve evliliğin devamı", "Türk vatandaşı ile evli yabancı eşin yazılı başvurusu"ndan ibarettir. TVK. md. 5'de ifadesini bulan, "aranılan şartlar", arasında, Gerekçe'de sözü edilen, "güvenlik soruşturması yapma" hususu yer almamaktadır. Kanun'da, Gerekçe'de değinilen bu şartı yansıtan, en ufak bir ibareye dahi yer verilmiş değildir. Kanun'da açıkça zikredilmemiş bir şartın, vatandaşlığa alınma şartı olarak kabul edilmesinin, Anayasa'nın 66. maddesinde öngörülen, "kanunilik ilkesi"ne uygunluk arzetmeyeceği açıktır. $^{14}$

Aynı gerekçeyle, doktrinde savunulduğunun aksine, yetkili makam, evlenmenin kanunen geçerli olup olmadığını dahi araştıramaz. Bu hükme varan kesinleşmiş bir iptal/butlan kararı bulunmadıkça, "yokluk hükmü" dışında, evlenmenin butlanı ya da iptaline yol açan nedenlerin varlığı, idarî makama, evliliğin geçersiz olduğu gerekçesiyle başvuruyu reddetme hakkı vermez. ${ }^{15}$ Benzeri şekilde, evlenmenin muvazaaya dayanmıyor olduğunun tespitinin de, vatandaşlığa alınma şartları arasında sayılması, Türk Vatandaşlığı Hukuku'na egemen olan Anayasal ilkeyi belirleyen ve Türk vatandaşlığının ancak kanun ile kazanılabileceğini hükme bağlayan 66 . maddesine aykırı bir sonuç yaratacaktır. ${ }^{16}$ Kanun koyucu, evliliğin sırf vatandaşlık elde etme amacıyla yapılmamış olduğunu belirleyebilmek için, "3 yıllık bir süre" öngörmüş̧ür. Dolayısıyla, fiilen 3 yıldır evli olmak, bizatihi muvazaalı bir evliliğin bulunmadı̆̆ını gösteren bir olgu olarak, Kanun'da yer almaktadır ve bu olgunun varlığı, muvazaalı bir evliliğin yapılmadığını tespit açısından gerekli ve yeterlidir. Kanun koyucu, tarafların muvazaalı evlenme saikinin başka olgularla ortaya konmasına imkân tanıyan adi bir karine tayin etmiş değildir.

Kanun'un son derece açık lâfzı karşısında, Türk vatandaşı ile evlenen yabancıların, 3 yıl süre ile fiilen evliliği birlikte yürütmek ve evliliklerinin devam etmesi kaydiyla, yetkili makamlara müracaat etmeleri halinde, başvuru makamının yapması gereken, Kanun'daki şartların varlığını

\footnotetext{
${ }^{14}$ Aksi yönde, bkz. Vahit DOĞAN : Türk Vatandaşlık Hukuku, B.3, Ankara 2003, sh. 7879 ve sh. $80-81$.

${ }^{15}$ Kanunen geçerli bir evliliğin varlığını, yabancının Türk vatandaşlığını kazanabilmesi için bir ön şart sayan karşı görüş için bkz. DOĞAN, age., sh. 77 ve bu sh.'da yer alan Dn. (45).

${ }^{16}$ Aksi yönde bkz. DOĞAN, age., sh. 78-80.
} 
tespitten ibarettir. Bu şartları gerçekleştiren bireyin başvurusunu red konusunda da takdir yetkisi bulunmamaktadır. Yani, bu halde yetkili makam kararı ile kazanma değil; seçme hakkının kullanılması ile kazanma söz konusudur. $^{17}$

Bireyin talebi üzerine, başvuru makamının yapacă̆ iş, inceleme ve araştırmaya dayanan bir "tespit"ten ibarettir. Bu durum, 5. maddede, "Başvuru üzerine, İçişleri Bakanlığı tarafından yapılacak inceleme ve soruşturma sonucunda, aranan şartları taşıdığı anlaşılan kişiler, bu durumun tespitine ilişkin karar tarihinden itibaren Türk vatandaşı olurlar" hükmü ile açıkça ifade edilmiş bulunmaktadır. Başka bir deyişle, yetkili makamın kararı kurucu değil; vatandaşlığa alınma şartlarının somut başvuru dahilinde gerçekleşmiş olup olmadığının belirlenmesinden ibarettir. ${ }^{18}$ Kanımızca, madde hükmüyle vurgulanmak istenen, vatandaşlığın, evlilik anından itibaren, yani, geçmişe etkili olarak kazanılamayacağıdır.

Telsikten söz edebilmek için, ilgilinin başvurusu üzerine, yetkili makamın vatandaşlığa alınma yönünde karar alması ve bu kararın kurucu nitelik taşıması gerekir. Yetkili makamın kararı olmadıkça, vatandaşlık kazanımından söz edilemez. Seçme hakkının kullanımında ise, başvuru yeterli olup; yetkili makamın yapması gereken tek şey, Kanun'da öngörülen şartların somut halde gerçekleşip gerçekleşmediğini belirlemekten ibarettir. $\mathrm{Bu}$ tanımlamalar dahilinde, TVK. md. 5'in, ilgiliye seçme hakkı tanıdı $\breve{~}$ hususunda herhangi bir şüphe yoktur. TVK. md. 5 'in, seçme hakkının tanımı bağlamında farklılık arz eden tek yanı, vatandaşlığın kazanım anı ile ilgilidir. Seçme hakkının kullanıldı̆̆ına ilişkin yazılı başvurunun yapıldığı an, kazanma anı iken, TVK. md. 5'de kazanma anı, şartların gerçekleştiğinin "tespitinin yapıldığı karar tarihinden itibaren"dir. Bu açıdan da, madde hükmü eleştiriye açıtır.

Kanun'un 5. maddesinde zikredilen 2. grup nedeniyle, "kanunen kazanma" başlığı altında yer alma uygunluk arz etse bile, yabancı ile evlenmenin, kişinin vatandaşlığını kendiliğinden sona erdirmediğine dair, çeşitli devletlerin mevcut Vatandaşlık Hukuku kurallarına dayanılarak yapılan bir tespit doğrultusunda ${ }^{19}$, bu ihtimalin uygulanma şansının düşük olması ve değişik 5. maddenin halen "vatansız" olanları, kişinin iradesine

\footnotetext{
${ }^{17}$ Nitekim, bu paralelde, TVK.'nun seçme hakkının kullanılması ile Türk vatandaşlığının kazanımını düzenleyen 12. ve 13. maddelerinin uygulanmasını gösteren Türk Vatandaşlığı Kanunu'nun Uygulanmasına İlişkin Yönetmelik' in 18. maddesinde, “Bu hakkın kullanılması için ...Yönetmeliğin 14. maddesindeki müracaat makamlarına dilekçe vermek kâfidir.... Bu makamlarca dileğinin doğruluğu tespit edildiği takdirde derhal tescilleri yapılır” hükmü yer almaktadır. 11 Şubat 1964 tarihli ve 403 Sayılı Türk Vatandaşlığı Kanunu'nun Uygulanmasına İlişkin Yönetmelik (Yönetmelik) için bkz. : RG. 01 Temmuz 1964, S. 11742.

${ }^{18}$ Değişik 5. maddenin son fikrasına göre, bu maddenin uygulanmasına dair usûl ve esaslar, Bakanlar Kurulu'nca çıkarılacak yönetmelikle belirlenecektir.

${ }^{19}$ AYBAY, agm ., sh. 22.
} 
dayanmayan evlilik hukukî işlemine bağlanmış kendiliğinden vatandaşlık kazanımını sağlayan bu istisnanın kapsamı dışında bırakmış bulunması karşısında da, 5. maddenin sistematik bütünlüğü bozduğu sonucuna varilacaktır. $^{20}$

5. madde ile ilgili olarak, bu kapsamda yapılması gereken bir diğer eleştiri de, bir Türkle evli olanlara vatandaşlık kazanma imkânı veren Kanun'un 7. maddesi ile birlikte ele alınarak, birbirini tamamlayıcı biçimde düzenlenmemiş olmasıdır. 7. maddeyle, "bir Türk vatandaşı"yla evli olanların, Türkiye'de 5 yıl süre ile ikamet etme ve yerleşme niyetinin varlığ şartları aranmaksızın, yetkili makam kararı ile Türk vatandaşlığını kazanabilecekleri öngörülmektedir. Dolayısıyla, bir Türk vatandaşı ile evlenen yabancı dilerse, 3 yıl beklemeksizin istisnaî vatandaşlığa alınma yoluna başvurarak, yetkili makam kararı ile Türk vatandaşı olabilecektir. Aradaki fark, 5. maddeye göre, 3 yıllık süre sonunda vatandaşlığın ilgilinin talebi üzerine, yetkili makamın "izni” aranmaksızın kazanılmasında yatmaktadır. ${ }^{21}$ Bu açıdan bakıldığında, bir Türk vatandaşı ile evlenen yabancı, 5. maddede öngörülen süreyi beklemeksizin, Türk vatandaşlığını kazanabileceğinden, değişik 5. madde düzenlemesi ile, vatandaşlığı kazanma niyetine dayalı muvaazalı evlilikleri önleme amacının gerçekleşmesi engellenmiş olmaktadır.

7. madde, 5. maddedeki bildirim sürelerini geçirenler dişında, "başlıca" 5. maddedeki kazanma yolunun sadece kadınlara tanındığ yabancı erkekler bakımından bir önem ifade etmekte ve vatandaşlığa alınmada kolaylık sağlamakta idi. Oysa, yeni 5. madde, uygulanma kapsamına yabancı erkekleri de almış bulunduğundan, artık 7. madde, Türk

\footnotetext{
${ }^{20}$ Avrupa Vatandaşlık Sözleşmesi'nin onaylanması halinde, TVK. 5. maddede yer alan bu istisnaî halin daha farklı bir biçimde düzenlenmesi gerekecektir. Zira, Sözleşme'nin 4/(d). maddesine göre, vatandaş ile yabancı arasındaki evliliğin kurulması, sona ermesi, evlilik süresince eşlerden birinin tâbiiyetindeki değişiklik, diğer eşin uyrukluğunu "kendiliğinden" etkileyemeyecektir. O halde, vatansızlık ya da vatansız kalma ihtimalinin bulunduğu hallerde, evlilik otomatikman Türk vatandaşlığını kazandıran bir etkiyi haiz olamayacaktır. Sözleşme'nin çekince hakkını düzenleyen 29. maddesine göre, II. Bölüm'de yer alan 4 . madde hakkında çekince konulması da mümkün değildir. Öte yandan, yine aynı maddenin (b) bendinde, üye devletlere, vatansızlığı önleme borcu da yüklenmektedir. Her iki durumun, birbiriyle uyumlu biçimde dikkate alınabilmesi, kanımızca vatansız ya da evlenme suretiyle kendiliğinden vatansız hale gelecek yabancıların bu yolla vatandaşlık kazanımını derhal ancak, ayrıca "eşin iradesinin varlığı" kaydına bağlamak uygun olacaktır.

${ }^{21}$ Değişik TVK. md. 5'in telsik olarak nitelendirilmesi nedenine dayanarak, 5. madde ile, yabancı erkeklere büyük bir kolaylık sağlanmış olduğunun kabul edilemeyeceği; esasen TVK.'nun istisnaî vatandaşlığa alınma şartlarını düzenleyen 7. maddesinde, ikamet etme ve yerleşme şartı dahi aranmayarak zaten bir kolaylık tanınmış olduğu; dolayısıyla, değişik 5 . maddenin Türkle evlenen yabancı erkeğe ek bir olanak sağlamadığı", sadece yabancı kadına önceki Kanun maddesiyle tanınan seçme hakkının sona erdirildiği yönünde, aksi görüş için bkz. AYBAY, age., sh. 97-98; AYBAY, agm., sh. 21.
} 
vatandaşı ile evli vatansız kadın ve erkek ile bu süreyi beklemek ya da 5 . maddeden yararlanmak istemeyen eşler bakımından hüküm ifade eder hale gelmiştir.

Bu nedenle, mevcut kanunî düzenleme dahilinde, ya md. 7/1/(a), 5 . maddenin kapsamı dışında kalan kişiler, yani, vatansızlarla sınırlı olarak yeniden düzenlenmeli; ya da bütünlüğü sağlamak amacıyla daha uygun olarak, 7. maddenin, 1. fıkrasının (a) bendi yürürlükten kaldırılmalı ve Türk vatandaşı ile evlenen vatansızlar bakımından evlenme nedeniyle vatandaşlık statüsünün kazanılmasını sağlayan bir hükme 5. maddede yer verilmelidir. Böylece, 7. maddenin, 5. maddenin uygulanabilirliğini fiilen ortadan kaldıran etkisi sona erdirilmiş olacaktır. Evlenme, Türk Hukukunda, Türk vatandaşı ile evlenen yabancının, diğer yabancılara nazaran Türkiye ile olan daha yakın/yoğun bir ilgi içinde olduğuna işaret eden bir unsur olarak nitelendirilmiş ve kanun koyucu bu düşünceden hareketle, durumu ayrı bir maddede düzenlemiştir. Hal böyle iken, evlenmenin, olağandan fazla bir yoğun ilgiyi esas alan kolaylaştırılmış yoldan yetkili makam kararıyla vatandaşlık kazanımını sağlayan 7. madde kapsamında değerlendirilmesine devam edilmesinin mantığ kalmamaktadır.

Benzeri şekilde, TVK.'nun 5. maddesinde yapılan bu değişiklik, "Bir Türk vatandaşı ile evlenme kararı ile Türkiye'de yerleşmiş olanlar"1n ikamet şartı aranmaksızın istisnaî yoldan Türk vatandaşlığı'nı kazanmasını imkân dahiline sokan TVK. md.7/(ç)'nin de, yeniden ele alınmasını gerekli kılmaktadır. ${ }^{22}$ Aksi halde, bir evlilik birliğine dayanmaksızın birlikte yaşayan çiftlerin Türk vatandaşlığını kazanmaları, evli çiftlere nazaran daha kolaylaştırılmış olmaktadır. ${ }^{23}$

\footnotetext{
${ }^{22}$ İlgili hüküm kanunlaştığı dönem itibariyle, yabancılar ile evlendikleri için, tâbi olduklan kanunlar itibariyle istifa etmiş sayılacak, bazı görevliler bakımından bir önem arz edebilirdi. Günümüzde, birtakım özel görev alanları itibariyle, yabancı ile evlilik ya Anayasa mahkemesi karanyla ya da ilgili kanunlarda yapılan değişikliklerle, istifa nedeni olmaktan çıkarılmış veya "izin almak" şartına bağlı olarak mümkün kılınmıştır. Ancak, bazı meslek grupları bakımından halen benzer yasaklamaların devam etmekte olması ihtimali dahilinde, gerekli görülür ise, TVK. md.5 ile uyumluluk arz edecek şekilde, sadece bu özel duruma münhasır bir düzenlemeyle, bağımsız bir telsik nedeninin Kanun metninde yer alması sağlanabilir. Bu görev alanları ile ilgili olarak bkz. : Ergin NOMER: Vatandaşlık Hukuku, B. 13, İstanbul 2002, sh. 70 .

${ }^{23}$ Bu madde hükmünün, evlilik dışı yaşamı desteklediği yönünde eleştiri için bkz.: NOMER sh. 81-82; Madde hükmü başka yönlerden de eleştirilmelidir. Yönetmelik'in 11/(ç) maddesi, bu bireylerin kimler olacağını, şu şekilde belirlemiştir: "muntazam pasaportla, iltica suretiyle veya herhangi bir şekilde Türkiye'ye gelmiş ve bir Türk vatandaşı ile karı-koca hayatı yaşamaya başlamış, çocukları olmuş veya evlenmeleri kararlaştırılmış ve bu maksatla da Türkiye'ye yerleşmiş olanlar". Yönetmelik'in bu hükmü ile bir yandan, 15 Temmuz 1950 tarihli ve 5682 sayıl Pasaport Kanunu ile, 15 Temmuz 1950 tarihli ve 5683 sayılı Yabancıların Türkiye'de İkamet ve Seyahatleri Hakkında Kanun hükümleriyle belirlenen sonuçlarına rağmen, ülkeye hukuka aykırı bir biçimde yapılan girişler mazur görülmekte; öte
} 
5. maddenin değişik hükmü karşısında, TVK. md. 14 ve TVK. md. 28 , TVK. md. 37 hükümleri de sorgulanır hale gelmiştir. Sözü edilen bu maddeler, orijinal 5. maddenin, evlenme suretiyle Türk vatandaşlığının kazanımını, sadece yabancı kadınlara tanıması nedeniyle öngörülmüştür. Eski Kanun maddesine göre, sadece "yabancı kadın"a Türk vatandaşlığını kazanma imkânı tanındığından, bunun doğal sonucu olarak, 14. maddede, "küçük çocuklar"ın da anneyi belirli şartlarla takip edebilmelerini sağlayan bir hükme yer verilmiştir. ${ }^{24}$ Yine, bu doğrultuda aynı mantıkla, Kanun'un 28. maddesinde, 5. maddeye dayanarak Türk vatandaşlığını kazanmış kadına, bu vatandaşlığı kazandıran evliliğin sona ermesinden başlayarak 3 yıl içinde, eski vatandaşlığına da dönebiliyor olmak kaydı ile ${ }^{25}$, Türk vatandaşlığından ayrılmayı sağlayan bir seçme hakkı tanınmıştır. Evlenme suretiyle Türk vatandaşlığına geçen annelerine bağlı olarak Türk vatandaşlığını kazanmış küçük çocukların, annelerinin 28. maddedeki seçme hakkını kullanması üzerine Türk vatandaşlığını kaybetmeleri ile; bu evlenmeden doğan küçük çocukların, seçme hakkını kullanan annelerine bağlı olarak Türk vatandaşlığını kaybetmelerini düzenleyen 37 . madde de aynı biçimde, kendi mantıksal kurgusu içinde 5. madde ile bir bütünlük arz etmekteydi. TVK. md. 5, artık modern teori dahilinde kadın/erkek ayrımı yapmaksızın genel olarak "eşler" bakımından bir etki yarattığına ve Yeni Türk Medenî Kanunu (TMK.) ile de Aile Hukuku bağlamında eşlere tanınan eşitlik, bu anlamda Türk Hukukuna ve toplumuna egemen olan eşitlik fikrini ortaya koyduğuna göre, kanun koyucu, 5. maddeyi değiştirirken bu maddelerde de gerekli değişikliği yapmalı idi. Sonuç olarak, 5. madde ile bağlantılı diğer maddelerin de benzeri değişikliğe uğramamasını ve kadın bakımından bir ayrıcalık yaratılmasını haklı kılan bir neden bulunmamaktadır.

Kanun'da, başvuru tarihinden itibaren İçişleri Bakanlığı tarafından yapılacak tespite kadar geçecek sürede, evliliğin sona ermesi halinde, bu durumun vatandaşlık kazanımını nasıl etkileyeceğine dair özel bir hüküm de bulunmamaktadır. Esasen, değişik 5. maddede, vatandaşlık kazanım anı, tespit anı olarak açıkça belirlenmemiş olsa idi; tanım gereği, başvuru anından itibaren seçme hakkını kullanan kişinin Türk vatandaşlığını kazanmış olduğu sonucuna varılabilirdi. Ayrıca, değişik 5. madde hükmü, evliliğin devamı kaydını bir şart olarak öngörmüştür ve "Iç̧işleri Bakanlığı'nca, aranılan şartları taşıdıkları anlaşılan kişiler”in Türk

yandan, TVK. md. 7'nin açık ifadesine aykırı biçimde "Türkiye'ye yerleşme" şartı aranmaktadır.

${ }^{24}$ TVK. md. 14'de, küçük çocukların, babanın ölmüş olması, belli olmaması, vatansız sıfatını taşıması ya da çocuğun vatansız sayılması hallerinde, velâyet hakkı olmayan anneyi takip ederek Türk vatandaşlığını kazanacak olmalan da eleştirilmesi gereken bir düzenlemedir.

${ }^{25}$ Kanımızca bu ibaresi ile de, Kanun maddesi eleştiriye açıktır. Amaç vatansızlığı önlemek olduğuna göre, önemli olan evlenmeden önceki vatandaşlığa dönebilmek değil; herhangi bir ülkenin vatandaşlı̆̆ını taşımaktır. 
vatandaşlığını kazanacaklarını ifade etmektedir. O halde, İçişleri Bakanlığı, karar tarihine kadar vatandaşlık kazanılmadığından, bu durumu göz önüne almak zorundadir.

5. madde bu kapsamda da eleştirilmektedir. Doktrinde, "Kanun'un sözünün bu kadar katı yorumlanmamas1; amaca göre yorum yöntemi ile, idarenin takdir yetkisini kullanırken, evliliğin hangi koşullarda ve hangi nedenle sona ermiş olduğunu dikkate alması; örneğin, evliliğin Türk eşin kusuru nedeniyle sona ermesi halinde bu durumun başvuruyu engellememesi gerektiğgi" ifade edilmektedir. ${ }^{26}$ Kanımızca, kolaylaştırılmış yollardan vatandaşlık kazanımında izlenen amaç, kişinin, sahip olduğu bazı özellikler dolayısıyla, diğer yollardan vatandaşlığa alınma başvurusunda bulunacak yabancılara nazaran bir ülkeyle ya da bu ülkeyle bir băg oluşturacak biçimde onun vatandaşlarından biriyle daha yakın bir ilişki içinde bulunan yabancıların, vatandaşlık kazanımlarını sağlamaktır; ve evlilik de, normalden daha sıkı bir bağı ortaya koyan nedenlerden biridir. Evlilik sona erdiğinde, bu özel bağ da ortadan kalkacağına göre; evlilik ilişkisinin varlığına dayalı özel bir vatandaşlık kazanımı imkânı sunmanın gereği kalmayacaktır. Dolayısıyla, "kanunilik ilkesi”ne uygunluk gereğince, amaçsal yorumdan hareketle de, maddenin mevcut hükmünün anlam itibariyle uygulanma alanının genişletilmesi mümkün olmamalıdır. Ancak, olması gereken açısından, istisnaen, Bir Türk vatandaşı ile yapılan ve 3 yıl devam eden evliliğin ölüm, butlan, iptal gibi bir nedenle sona ermesi halinde, hak düşürücü belli bir süre dahilinde, mevcut olmayan bir evlilik birliğine rağmen, Türkiye ile daha yakın bir ilginin varlığını ortaya koyan bir hususun mevcudiyeti halinde, vatandaşlığa bu yolla başvuru hakkının verilmesi daha uygun olurdu. Nitekim, evliliğin sayılan nedenlerden birine dayanılarak sona ermesi durumunda, bu evlilikten doğan ve Türk vatandaşlı̆̆ını taşıyan çocukların velâyetinin yabancı eşe verilmiş olması kaydıyla, kısa bir süre içinde, 5. maddeden yararlandırılması să̆lanabilirdi. ${ }^{27}$

TVK. md. 5 değişikliği ile ilgili olarak söylenmesi gereken son husus, maddede başvuru sahibinin ehliyetine dair bir şarta yer verilmemiş olmasıdır. Evlenme anında reşit olmayan ve millî kanununa göre, evlenme sebebiyle de reşit duruma gelmeyen yabancı eş, Türk vatandaşlığına alınma başvurusunu yaptığı sırada da, millî kanunu hükümleri gereğince halen reşit değilse, bu başvuruyu yapabilecek midir? Verilecek yanıt olumlu ise,

\footnotetext{
${ }^{26}$ AYBAY, age., sh. 99 vd. ; AYBAY, agm., sh. 22.

${ }^{27}$ Alman Vatandaşlık Kanunu (Staatsangehörigkeitsgesetz) § 9/2'ye göre, Alman vatandaş1 ile yapılan evlilik, ölüm, boşanma, butlan ya da iptal gibi bir nedenle sona ererse, bu evlilikten doğmuş ve Alman vatandaşlı̆̆ını taşıyan çocuğun velâyeti yabancı eşte bulunmak kaydıyla, ölüm anı veya evlenmeyi sona erdiren kararın kesinleştiği tarihten itibaren "bir yıl süre" içinde, yabancı eşe, "evlilik nedenine dayalı" vatandaşlık kazanımı imkânı tanınmaktadır. Bkz. http://www.gesetzesweb.de/StAG.html (12 Aralık 2003 tarihi itibariyle).
} 
başvuruyu, bizzat mı yoksa, kanunî temsilcisi aracılığıyla mı gerçekleştirebilecektir? Yine, evlenme akdinden sonra ortaya çıkan bir nedenle, yabanc1 eşin temyiz kudretini yitirmiş veya evlenme akdi sırasında ya da sonradan vesayet altına alınmış bulunması, evlenme suretiyle vatandaşlık kazanımı başvurusunu nasıl etkileyecektir?

$\mathrm{Bu}$ sorunu gidermek bağlamında, TVK. md. 5'e, ehliyet şartına dair bir hüküm eklenmesinin uygun olacağı düşünülmektedir. ${ }^{28}$

\section{Evlenmenin Çocukların Vatandaşlık Statüsüne Etkisi}

TVK.'nun 5. maddesinin eski ve yeni metninde, butlanına karar verilmiş evlenmeden doğan çocukların anne ve/veya babaları iyiniyetli olmasalar bile, kazandıkları Türk vatandaşlığını devam ettirecekleri ifade edilmektedir. Aslında, bu hüküm bulunmasaydı bile, geçersiz evlilikten doğan çocuklar, zaten Kanun'un 1. ve 2. maddelerine göre, Türk vatandaşlığını, anne ya da babaya göre aslî yoldan kazanabileceklerdir. Sorun, evlenmenin butlan nedeniyle geçersizliği halinde, 1982 tarihli ve 2675 sayılı MÖHUK. hükümleri çerçevesinde evlenmenin butlanını tayin eden yetkili yabancı hukukta, butlanla batıl bir evliliğin butlan kararına kadar geçerli bir evliliğin tüm hüküm ve sonuçlarını doğuracağına dair bir hükmün yer almaması halinde ve yine, MÖHUK. hükümlerine göre, çocuk ile Türk vatandaşı ana/baba arasında nesep bağının da kurulamamasına bağlı olarak ortaya çıkacaktır. Bu açıdan bakıldığında, 5/ 4. fık. hükmünün yerinde bir düzenleme olduğu söylenebilir.

Bunun dışında, eski 5. maddede düzenlenmeyen bir husus, maddenin yeni metninde de yine yer almamaktadır. Evlenmenin butlanına karar verilmesi halinde, evlenmeye bağlı olarak 14. madde gereğince, Türk vatandaşlığını kazanmış küçük çocukların, vatandaşlıklarının devam edip etmeyeceği hususu düzenlenmemiştir. Eski Kanun maddesinde de aynen yer alan, 3. f1kra uyarınca, iyiniyetli olmasa dahi, kadının butlan müeyyidesine tâbi bir evlilik ile Türk vatandaşlığını butlan kararına kadar devam ettirmesi mümkündür. Zira, maddede belirtildiği üzere, evlenmenin butlanı halinde, bu evlilik ile Türk vatandaşlığını kazanmış bulunan eş, vatandaşlığını "iyiniyetli olmak" kaydıyla "muhafaza" edecektir. Yani, iyiniyet, vatandaşlığın kazanımı değil; kazanılan vatandaşlığın muhafaza edilmesi şart1 olarak öngörülmüştür.

\footnotetext{
${ }^{28}$ Genel olarak vatandaşlığa alınma şartlanını düzenleyen, Staatsangehörigkeitsgesetz (StAG), $\S 8 / 1$, konuya ilişkin bir hüküm içermektedir ve 9 . maddede yapılan atıf dolayısıyla, evlenme nedeniyle yapılacak vatandaşlığa alınma başvurusu hakkında da uygulama alanı bulmaktadır. Maddeye göre, "Alman Yabancılar Kanunu md. 68/1. fik.'da belirlenen koşullar çerçevesinde, fiil ehliyeti olmayanlar (reşit olmayan mümeyyizler), kanunî temsilcileri aracılı̆̆ıyla, vatandaşlığa alınma başvurusunda bulunabileceklerdir. Alman Yabancılar Kanunu'nun ilgili maddesi için bkz. http://wwwwbs.cs.tu-berlin.de/cgi/gesetze/AuslG/ data/80917.html (30 Ocak 2004 tarihi itibariyle).
} 
Buna bağlı olarak, geçersiz de olsa yapılan evlilik, 14. madde şartları dahilinde, kendiliğinden, küçük çocuklara Türk vatandaşlı̆̆ını kazandıracaktır. Butlan kararından sonra ise, kazanılan vatandaşlığın devam edip etmeyeceğini açıklayan bir Kanun hükmü bulunmamaktadır. Dolayısıyla, 1982 tarihli Anayasa'nın 66. maddesinin, "vatandaşlık kanunun gösterdiği şartlarla kazanılır ve ancak kanunda belirtilen hallerde kaybedilir" hükmünden hareketle, varılacak sonuç, haklarında açık bir kanun hükmü bulunımadı̆̆ından, adı geçen küçük çocukların, vatandaş kalmaya devam edecekleridir. Kanunla kazanma ilkesinin doğal sonucu olarak, vatandaşlığın kazanımı ve kaybı halleri ve şartlarının tespiti bağlamında "kıyas", "geniş yorum" yasă̆ 1 esas olacağından ve "boşluk doldurma", mümkün bulunmadığından, farklı durumlar için hüküm içeren Kanun maddelerinden hareketle bir sonuca varmak da mümkün olmayacaktır. Dolayısıyla, küçük çocuklar için, seçme hakkını kullanarak Türk vatandaşlığından ayrılan kadının çocuğunun, Türk vatandaşlığını kaybını düzenleyen 37. maddenin kıyasen uygulanması ya da 5. maddenin, "butlanına karar verilmiş evlenmeden doğan çocuklar"la sinırlı hüküm getirmesinden hareketle, kanun koyucunun suskunluğunun bir boşluk olarak nitelendirilerek, vatandaşlığın kaybı biçiminde doldurulması ya da bu hükmün mefhumu muhalifine dayanılması olası değildir. ${ }^{29}$

\section{YETKILI MAKAM KARARI İLE YENIDEN VATANDAŞ- LIĞA ALINMA}

\section{TVK. md. 8'den Yararlanacak Olanlarm Tespiti}

4866 sayılı Kanun'un 3. maddesi ile yapılan bir diğer değişiklik de, 403 sayılı TVK.'nun 8. maddesine ilişkindir. Yeni madde metni, Türk vatandaşlığının bu suretle kazanımını, önemli ölçuide sınırlandırmış ve daha önce Türk vatandaşı iken herhangi bir suretle Türk vatandaşlığını sonradan kaybeden bazı kişiler bakımından, bu imkânı ortadan kaldırmış bulunmaktadır. Kanun koyucunun, bu sınırlamayı bilinçli bir şekilde gerçekleştirmemiş olduğu sonucuna; 403 sayılı Türk Vatandaşlığı Kanunu'nun Uygulanmasına Dair Yönetmelik'in 12. maddesinde ${ }^{30}$ orijinal 8. madde bağlamında yapmış olduğu eksik tasnifi aynen esas alarak, kanunî metin haline getirmiş olmasından hareketle varılabilecektir. Yeni metninden farklı olarak, orijinal 8, madde, çıkarma hali hariç, 403 sayılı TVK. hükümlerine göre herhangi bir yolla vatandaşlığını kaybetmiş her bireye, yeniden vatandaşlığa alınma talebinde bulunma imkânını vermekteydi.

\footnotetext{
${ }^{2 y}$ Aksi yönde bkz. NOMER, age., sh. 68 .

30) Yönetmelik Kanun değişikliklerine bağlı olarak çeşitli dönemlerde değişikliğe uğramıştır. Ancak, bunlardan bazıları Resmî Gazete'de yayımlanmamıştır. Oysa, 24 Mayıs 1984 tarihli ve 3011 sayılı Resmî Gazetede Yayımlanacak Olan Yönetmelikler Hakkında Kanun'un 1/(c). maddesine göre, kamuyu ilgilendiren yönetmeliklerin yayımlanması zorunludur. Bkz. RG. 01 Haziran 1984, S. 18418.
} 
Başka bir ifade ile, 8. maddede, 35. madde hükmünde de yer alan vatandaşlıktan çıkarma kararıyla çıkarılanların hiç bir suretle Türk vatandaşı olamayacağı ifadesi, bir kez daha zikredilmek suretiyle; bu halin dişındaki "tüm" vatandaşlık kaybı hallerinin 8. madde hükmü kapsamına dahil olduğu, vurgulanmıştı. ${ }^{31}$ Kanun maddesinin açıklanmasına yönelik Yönetmelik'in 12. maddesinde ise, bu kişiler, Kanun'un açık ifadesine rağmen eksik bir biçimde üç grup halinde sayılmakta idi. Yönetmelik'in 12. maddesinde sayılan bu kişiler, sırasıyla, "TVK. 'nun 19. maddesi uyarınca yabancı erkekle evlenmek ve kocasının tâbiiyetini seçmek suretiyle Türk vatandaşlığını kaybeden kadınlardan, evliliğin sona ermesinden itibaren 3 yıllık başvuru süresini geçirmiş olanlar; resmî izinle TVK. md.20 hükmü gereğince Türk vatandaşlığından çıkanlar; TVK.'nun 25. maddesi gereğince Bakanlar Kurulu'nca Türk vatandaşlığını kaybettiklerine karar verilenler"dir. Kanun koyucu, Yönetmelik'in bu hükmünü aynen koruyarak kanun metni haline getirmiş bulunmaktadır. Bu nedenle, aşağıda belirlenen kişiler artık, bu yolla, Türk vatandaşlığına alınmalarını talep edemeyeceklerdir:

1. 403 sayılı Kanun'a göre, seçme hakkını kullanarak, Türk vatandaşlığını kaybetmiş kişiler; yani,

a. TVK. md. 27 gereğince, reşit olmalarından başlayarak iki yıl içinde seçme haklarını kullanmak suretiyle, Türk vatandaşlığından ayrılmış bulunanlar;

b. evlenme suretiyle Türk vatandaşı olmuş ve daha sonra TVK. md. 28'deki seçme hakkını kullanarak Türk vatandaşlığını kaybetmiş kadınlar;

2. TVK.'nun 19. maddesi uyarınca Türk vatandaşlı̆̆ını, yabancıyla evlenerek, "kanun yoluyla" kaybetmiş ve evliliği halen devam etmekte olan eski Türk vatandaşı kadınlar;

3. ana veya babalarını takip ederek Türk vatandaşlığını kaybetmiş ancak, TVK. md. 12 uyarınca reşit olmalarından başlayarak 1 yıl içinde seçme haklarını kullanmamış/kullanamamış çocuklar:

a. TVK. md. 30 ve 37 uyarınca, Türk vatandaşlığını analarına bağlı olarak kaybetmiş küçük çocuklar,

b. TVK. md. $32^{32}$ ve 36 gereğince, Türk vatandaşlı̆̆ından çıkan ana/ babalarını takip eden küçük çocuklar;

\footnotetext{
${ }^{31}$ Kanun maddesinin yeni metninde ise, vatandaşlıktan "çıkarma" kararı ile çıkarılanların yeniden vatandaşlığa alınma yolundan yararlanamayacağına dair ibare yer almamaktadır. Yeni metindeki sınırlı sayıda sayım, zaten bu tekrarı gereksiz kılmaktadır.

${ }^{32} \mathrm{Bu}$ kategorideki küçük çocuklar, TVK. md. 8'de sayılan Türk vatandaşlığını "çıkma kararıyla" kaybetmiş kişiler arasında sayılmamalıdır. Zira, çıkma izni hukukî sebebine dayalı olarak; uygulama alanı bulsa da, TVK. md. 32 nedeniyle, "kanun yolu ile irade dışı kayıp hali” söz konusudur.
} 
4. TVK. md. 23/2. fikra uyarınca, başka bir devlet vatandaşlığını kazanmak için izin almış; ancak, üç yıl içinde yetkili makamlara gerekli bilgi ve belgeyi vermediği için Türk vatandaşlı̆̆ına, kaybettirme kararı ile son verilmiş kişiler ${ }^{33}$;

5. yetkili makam kararı ile Türk vatandaşı olmuş; daha sonra haklarındaki vatandaşlığa alınma kararı iptal edilmiş bireyler: TVK. md. 33/2. fik. gereğince iptal kararları geri yürümeyeceğinden ${ }^{34}$, iptal kararının verilmesi de, Türk vatandaşı̆ı̆ını kayıp hali yaratır. Dolayısıyla, eski Kanun metni dahilinde, yeniden vatandaşlığa alınmaları mümkün olan bu kişiler $\mathrm{de}^{35}$ kapsam dışı bırakılmış olmaktadır.

Yeniden vatandaşlığa alınma başlığını taşıyan 8. maddenin esprisi, daha önce herhangi bir nedenle Türk vatandaşlığını taşımış yabancıları, diğer yabancılara nazaran kolaylaştırılmış şartlarla Türk vatandaşlığına almaktır. $\mathrm{Bu}$ nedenle, kanun koyucunun, TVK.'na göre Türk vatandaşlığını kaybetmiş bireyler arasında neden böyle bir ayrıma gitme ihtiyacı hissettiği anlaşılamamaktadır.

\section{Yeniden Vatandaşlığa Alınma Kararı Verecek İdarî Makamın ve Yetkisinin Niteliğinin Tespiti}

TVK.'nun orijinal metninde, 8. maddeye göre yeniden Türk vatandaşlığını kazanacak kişiler hakkında, vatandaşlığa alınma kararı verecek makam, Bakanlar Kurulu olarak belirlenmişti. Ancak, yapılan değişiklikle bu yetki, vatandaşlığın kayıp nedenlerine göre paylaştırılmış bulunmaktadır. Buna göre, TVK. md. 19 hükmüne göre Türk vatandaşlığını kaybeden ve TVK. md.13'de öngörülen süreyi geçiren kadınlar ve TVK. md. 20 uyarınca, Türk vatandaşlığını çıkma kararı ile kaybeden eski Türk

\footnotetext{
${ }^{33}$ Yönetmelik'in 34. maddesinin 4. fikrasındaki, "Bakanlar Kurulu'nca Türk vatandaşlı̆̆ını kaybettiğine karar verilenler, bu kararın Resmî Gazete'de ilânından sonra istediği devlet vatandaşlığını kazanamadığından bahisle, yetkili Türk makamlarına başvururlarsa, haklarında 8. madde hükmü uygulanır" hükmü bu kişilerin 8 . maddeden yararlanabilmelerini düzenlemekte idi. Yeni Kanun metni ile uygulanabilirliğini yitiren bu Yönetmelik hükmü, değişiklikten önceki dönemde eleştiriye açıktı. Zira, orjinal 8. maddede yer almayan bir sınırlama içermekte idi. Bireyin, yabancı bir devlet vatandaşlığını kazansın ya da kazanmasın 8 . maddeye dayanarak başvuruda bulunması mümkündü.

${ }^{34}$ Yönetmelik'in 30. maddesinde, Kanun'un bu açık hükmüne rağmen, iptal kararlarının geriye etkili olduğuna dair, bir hükme yer verilmiş bulunmaktadır. Yönetmelik'in ilgili maddesi', 1982 tarihli Anayasa'nın, “....kanunların ve tüzüklerin uygulanmasını sağlamak üzere ve bunlara aykını olmamak şartıyla yönetmelikler çıkartılabileceği”ni öngören 124 . maddesi hilâfına bir hüküm niteliği taşımaktadır.

${ }^{35}$ Bu sınıflandırma için bkz.: Erdoğan GÖĞER: Türk Tâbiiyet Hukuku, B. 4, Ankara 1979, sh. 85-86; Ancak yazar, ilgili sunıflandırma dahilinde, TVK.'nun 8. maddesinin vatandaşlığa alınma kararının iptali suretiyle Türk vatandaşlığını kaybeden kişileri kapsamayacak biçimde yorumlanması gerektiğini de ifade etmektedir. Bu konuda ayrıca bkz.: Vahit DOĞAN: Türk Vatandaşlık Hukuku, Ankara 2002, sh. 102.
} 
vatandaşlarının yeniden Türk vatandaşlı̆̆ına alınmaları, İçişleri Bakanlığı'nın kararına bağlıdır; TVK. md. 25 hükmü gereğince, Türk vatandaşlığını kaybettirme kararı ile kaybeden eski Türk vatandaşlarının yeniden vatandaşlığa alınmalarına ise, Bakanlar Kurulu karar verecektir. Bu halde, TVK. md. 6 da öngörülen şartlardan "ikamet şartı"aranmayacaktır ${ }^{36}$ ve yetkili makamların, konu bakımından nihaî bir takdir yetkisi bulunmaktadır. Bu takdirî yetki, 4866 sayılı Kanun'un 2. maddesinde yer alan "yeniden vatandaşlığa alınabilir" ifadesi ile belirlenmiş bulunmaktadır.

Yetkinin, TVK. md. 19 ve md. 20'ye göre Türk vatandaşlığını kaybedenler bakımından, İçişleri Bakanlığı'na verilmesi, pratikte, ilgililerin taleplerinin ve haklarındaki işlemlerin daha kısa sürede sonuçlandırılması; Bakanlar Kurulu'nun gereksiz bir iş yükünden kurtarılması düşüncesine dayanmaktadır. TVK. md. 25 hükmüne dayanılarak hakkında kaybettirme kararı alınmış kişilerin yeniden vatandaşlığa alınma talepleri hakkında karar verme yetkisi ise, kaybettirme kararını vermeye yetkili makam ile yetkide paralelliği sağlayabilmek düşüncesiyle yine, Bakanlar Kurulu'na

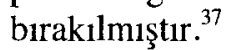

Sözü edilen değişiklik, 403 sayılı Kanun'un 10. maddesinde de değişiklik yapılmasını gerekli hale getirmektedir. Nitekim, "Şartsız olarak vatandaşlığa alınma Bakanlar Kurulu kararı tarihinden itibaren hüküm ifade eder", hükmünü içeren 10. maddenin 1. fikrası, "vatandaşlığa alınma kararının İçişleri Bakanlığı' na ait olduğu hallerde, vatandaşlığa alınmanın

\footnotetext{
${ }^{36}$ Avrupa Vatandaşlık Sözleşmesi'nin 9. maddesine göre, eski vatandaşların yeniden vatandaşlığa alınmaları, ülkede hukuka uygun biçimde ikamet etme kaydı ile, her üye devletin iç hukuk kurallarıyla belirlenen haller ve koşullarla kolaylaştırılabilecektir. Yine, md. 15/1/(b)'ye göre, sahip olunan vatandaşlığın sona ermesi koşulu da aranabilecektir. Ancak, üye devletlere, bu maddelerin içinde yer aldığı IV. Bölüm bakımından, Sözleşme'nin amacına uygun düştüğü ölçüde mümkün olmak üzere kullanılabilecek bir çekince hakkı da tanınmış bulunmaktadir (md. 29).

${ }^{37}$ İçişleri Komisyonu Raporu'nda yer aldığ 1 üzere, hem çıkma iznini verecek makam; hem de yeniden vatandaşlı̆̆a alınma talebinde bulunan bazı eski Türk vatandaşları hakkında karar vermeye yetkili makam olarak, İçişleri Bakanlığı'nın gösterilmiş olmasının dayandırıldığı gerekçe şudur: “...Türk Vatandaşlı̆̆ı Kanunu'nda, çıkma izni verme ve yeniden vatandaşlığa alma yetkisinin Bakanlar Kurulu'na verilmiş olması bir çok sorun yaratmaktadır. İlk olarak yurt dışında yaşayan vatandaşlar, çıkma işleminin uzaması nedeniyle mağdur olmakta; hak kaybına uğramaktadırlar. İkinci olarak, Bakanlar Kurulu gereksiz ve yararsız bir iş yükü ile karşı karşıya kalmaktadır. Çünkü, bu konudaki araştırma ve işlemlerin tümü İçişleri Bakanlığı tarafından yürütülmektedir. Üçüncü olarak, gereksiz yere yazışmalar yapılmakta, zaman, enerji ve kaynak israfı ortaya çıkmaktadır. Bu nedenle, ...TVK.'nun 8., 20., 29. maddelerinde değişiklik yapılarak, yetki Bakanlar Kurulu yerine, İçişleri Bakanlığı'na verilmektedir. Bakanlar Kurulu kararıyla vatandaşlığın kaybettirilmesi halinde ise, tersine işlem teorisine uygun olarak, vatandaşlığa yeniden alınma için Bakanlar Kurulu kararı aranmaktadır". Bkz. http: // www. tbmm. gov . tr / sirasayi / donem22 / yil01 /ss115m.htm (19 Aralı 2003 itibariyle).
} 
İçişleri Bakanlı̆̆ı'nın kararı tarihinden itibaren hüküm ifade edeceği"ni öngören bir fikra eklenmesi gerekli hale gelmiş bulunmaktadır. Yine 10 . maddenin, sartlı vatandaşlığa alınmayı düzenleyen sonraki fikralarının da, 8 . maddenin İçişleri Bakanlığı'na verdiği yetki doğrultusunda aynı yönde değiştirilmesi gerekecektir. Sartlı vatandaşlığa alınma, 8. maddeye dayanarak başvuran bireyler bakımından da mümkün olabildiği için, 10 . maddenin 2. ve 3. fikrasında yer alan Bakanlar Kurulu ibaresi, "...ve 8. maddeye göre başvuru yapıldığı hallerde İçişleri Bakanlığı..." ifadesi eklenerek yeniden kaleme alınmak durumundadır.

\section{YETKILI MAKAM KARARI ILE TÜRK VATANDAŞ- LIĞINDAN ÇIKMA}

403 sayılı TVK.'nun 20. ve 32. maddelerinde değişiklik yapan 4866 sayılı Kanun'un 3. ve 5. maddeleri ile, sırasıyla, çıkma iznini verecek yetkili makam, Türk vatandaşlı̆̆ından kendi iradesiyle çıkmak isteyenlerin tâbi olacağg 1 şartlar ile, Türk vatandaşlığından çıkmanın çocukların tâbiiyeti üzerindeki etkisi yeniden düzenlenmiş bulunmaktadır. Yine, aynı Kanun'un 4. maddesi, bu değişimin gereği olarak, Türk vatandaşlığının kaybının sonuçlarını genel olarak düzenleyen 29. maddede de bir düzeltme yapmıştır.

\section{1. Çıkmanın Şartları}

403. sayılı TVK.'nun 20. maddesinde sayılan ç1kma şartlarına, 4886 sayılı Kanun'la, iki yeni şart daha eklenmiş bulunmaktadır. Bunlar, herhangi bir suç nedeniyle aranmakta olan kişilerden olmamak (md. 3/(c)) ve talep sahibinin hakkında herhangi bir malî ve cezaî sınırlama bulunmamaktır (md. $3 /(\mathrm{c}))^{38}$

\footnotetext{
${ }^{38}$ Bu iki şart dahilinde, TVK.'nun orijinal metninde yer alan 07 Haziran 1995 tarihli ve 4112 sayılı Kanun ile ilga edilen "askerlik görevini yapmış olma" şartı da dolaylı olarak, vatandaşlıktan çıkma izni için aranır hale gelmiş olmaktadır. Zira, Askerî Mevzuat dahilinde, askerlik hizmetinden kaçınma, bir suç teşkil edebilecektir. Bu halin dışında, mevcut Kanun hükmü, Içişleri Bakanlığı’nın, sahip olduğu takdir yetkisini, askerlik hizmetini yapmış olma şartını arayarak, idarî işlemin sebep unsurunu genişletecek biçimde kullanabileceği endişesini de yaratmaktadır. Her ne kadar, takdir yetkisinin hukuka uygunluğu, yargı denetimine tâbi olacak ise de, konu bakımından takdir yetkisi tanınmış bulunması, bu tür kullanım ihtimalini de yaratmış olmaktadır. Danıştay'ın, idarenin idarî işlemin sebep unsurunu genişletecek ölçüde takdir yetkisi kullanamayacağı yönünde Vatandaşlık Hukuku'na ilişkin kararları için bkz.: Osman Fazıl BERKİ / Tuğrul ANSAY/ Tuğrul ARAT: Devletler Hususî Hukuku ile İlgili Danıştay ve Yargitay Kararları, C. I (Tâbiiyet Hukuku), Ankara 1975, sh. 1721; Günümüz itibariyle, çıkma talebi bağlamında askerlik yapma şartının kaldırıldığı; kendisini artık bağı hissetmediği için bir devletin vatandaşlığından ayrılma talebinde bulunan bir kişinin bu görevi yerine getirmeye zorlanmasının beklenemeyeceği görüşünün hâkim hale geldiği ifade edilmektedir. Bkz. GÖĞER, age., sh. 129-130; Her devletin, jeostratejik konumu dolayısıyla izlediği, savunma, nüfus, vatandaşlık politikasının birbirinden farklı olduğu, bu nedenle, askerlik hizmeti ile vatandaşlık arasında bir bağın kurulmaması gerektiği yönündeki düşüncenin, evrensel bir kabul görmesinin oldukça güç bulunduğu
} 
TVK.'nun 20. maddesine ilişkin olarak yapılan bu değişiklik, Anayasa'nın 66. maddesinde ifadesini bulan "kanunilik ilkesi"ne aykırı biçimde, uygulamada zaten aranmakta olan her iki şartın, bir kanun hükmüne dayandırılarak, hukuka uygun hale getirilmelerini sağlamak açısından önem arz etmektedir. ${ }^{39}$

Sözü edilen her iki şart da, idareye sebep bakımından takdir yetkisi tanıyan soyut kavramlar olarak kaleme alınmış gibi gözükmektedir ${ }^{40}$. Ancak, bu şartlar, Malî Hukuk, Ceza ve Askerî Ceza Hukuku kuralları çerçevesinde suç teşkil eden ya da mükellefiyet doğuran fiillerden hareketle objektifleştirilebilecek ve somutlaştırılabilecek sebeplerdir. Suç teşkil eden fiilin tayini, ve malî yükümlülükler (vergi, resim, harç, kambiyo, gümrük), "kanunilik ilkesi" gereğ $i^{41}$ son derece objektif biçimde belirlenebilmeye müsaittir. Yine, cezâi ( gözaltına alma, tutuklama, ülke dışına çıkış yasağı koyma, mahkûmiyet kararı alınması, para cezası, kamu hizmetlerinden yasaklanma, meslek tatili..) veya malî bir sınırlamanın kaynağının kanun olması ve bu sınırlamanın yetkili organlarca kanuna dayanılarak verilmiş bir karara dayanması gerektiğinden, bu sebebin somutlaştırılmasında da bir sorun yaşanmayacaktır. " Kanun md. 3/(d)'de yer alan malî ve cezaî sınırlama ibaresindeki "ve" sözcüğünün de, "veya" biçiminde anlaşılması uygun olacaktır.

yönünde aksi görüş için bkz.: Turgut TURHAN: Kuzey Kıbrıs Türk Cumhuriyeti Yurttaşlik Hukuku, Ankara 2002, sh. 73.

${ }^{39}$ Değişiklikten önceki döneme ait hukuka aykırı bu uygulamayı tespit için bkz.: Amir ÇIÇEK: Vatandaşık ve Yabancılar Hukuku Alanında Gelişmeler- Bilimsel Toplantı, İstanbul 24-25 Eylül 1998, İstanbul 2000, sh. 84; Doktrinde, "önceki düzenlemenin aksine, İçişleri Bakanlığı'na bir takdir yetkisi tanındığı; bu nedenle yetkili makamın, öngörülen şartlan taşıyan kişiye çıkma izni verme zorunluluğu bulunmadı̆̆ aranan ya da hakkında malî veya cezaî tahdit bulunan kişinin, Kanun'da özel olarak ifade edilmeseydi dahi, zaten çıkma izni alamayacağı; dolayısıyla, Kanun'a eklenen bu iki şartın bir anlam ifade etmeyeceği" görüşü dile getirilmektedir.: DOĞAN, age., sh. 121; Oysa, kanımızca, yukarıda da işaret edildiği üzere, yetkili makamın kendisine tanınan takdir yetkisini kullanarak, vatandaşlıktan çıkmaya dair bu iki şartı belirlemesi, başka bir deyişle, ancak açık bir kanun hükmüyle belirlenebilecek vatandaşlıktan çıkma şartlarına, idare tarafından, Kanun'da yer almayan yeni şartlar eklenmesi, Anayasa'nın 66. maddesinde vurgulanan "kanunilik ilkesi"ni zedelemek anlamına gelecekti.

${ }^{40}$ Eklenen şartların, sınırlarının belirsiz ve idareye verilmiş takdir yetkisinin kapsamının bu ölçüde genişletilmesinin yerinde olmadığı yönünde görüş için bkz. AYBAY, age., sh. 149; DOĞAN, age., sh. 121.

${ }^{41}$ Ceza Hukuku bağlamında bkz. Nur CENTEL: Türk Ceza Hukukuna Giriş, B. 2, İstanbul 2002, sh. 14 vd; Sulhi DÖNMEZER/Sahir ERMAN: Nazarî ve Tatbikî Ceza Hukuku, Genel Kısım, C.I, B. 13, İstanbul 1997, sh.17 vd.

${ }^{42}$ Ceza ve onun yerine geçen güvenlik tedbirlerinin, ancak kanunla konulabileceği hakkında Anayasal ilke için bkz.: 1982 tarihli Anayasa md. 38/2. 
TVK.'nun 20. maddesine eklenen bu iki şart ile ilgili olarak öne sürülen gerekçe, yeniden vatandaşlığa alınabilme ve izinle vatandaşlıktan çıkmanın avantajlarından yararlanabilme imkânları dahilinde, bu durumun çeşitli sorunlar yaratabilecek nitelikte görülmüş olması ve bu nedenle söz konusu boşluğun giderilmesi ihtiyacıdır. ${ }^{43}$ Ancak, bu konuda, gerek Ceza Hukuku ${ }^{44}$, gerekse Malî Hukuk alanında ${ }^{45}$ ortaya çıkabilecek sakıncalara dair somut örneklere, ne TBMM. İçişleri Komisyonu Raporu'nda ne de Taslak Gerekçesinde yer verilmiş bulunulmaktadır. Böyle bir şart, ancak, bir suçun takibinin ya da malî yükümlülüğün devamının Türk vatandaşı olma şartına bağlanması halinde bir değer ifade edecektir. Oysa, kural olarak, başta "herkes"e vergi ödevi yükleyen Anayasa md. 73 ve "kimse" ibaresini esas alarak, suç ve cezalara ait ilkeleri belirleyen Anayasa md. 38 olmak üzere, mer'i kanunlarımızda, suçun Türkiye'de işlenmesi ya da Türkiye'de bulunma; malî mükellefiyetin kapsamının tayininde, Türkiye'de yerleşik olma kriterleri esas alınmakta olduğundan, muhtemel bir suç dolayısıyla takip edilme, ceza dâvası açılma ve hükmün infazı ile; mükellef olma ehliyeti bakımından vatandaş/yabancı ayrımının bir önemi ve dolayısıyla

\footnotetext{
${ }^{43}$ İçişleri Komisyonu Raporu'nda, , "bu kişilerin vatandaşlıktan çıkmalarına izin vermenin, yeniden vatandaşlığa alınma kurumu ve izinle vatandaşlıktan çıkmanın avantajları ile birlikte düşünüldüğünde, çeşitli sorunlar yaratabilecek nitelikte" görüldüğü ve bu nedenle ilgili boşluğu doldurmak için önerge verildiği ifade edilmektedir. Bkz. http: // www. tbmm. gov . tr / sirasayi / donem22/yil01/ss115m.htm (19 Aralık 2003 itibariyle ).

${ }^{44} \mathrm{Bu}$ kapsamda, diplomatik/konsoler dokunulmazlık gibi, uluslararası teamül kuralları ve uluslararası sözleşmelerle sağlanan "cezaî bağışıklık" bir yana bırakılacak ołursa, mevcut kanunlarımıza baktığımızda, TCK. md. 3'de Türkiye'de suç işleyen herkes, vatandaş / yabancı ayrımı yapılmaksızın, TCK. hükümlerine tâbi kılınmıştır. TCK. md. 5 ve md. 6 çerçevesinde de, Türkiye dışında bir Türk ya da Türkiye aleyhine işlenen suçlar bakımından vatandaş/ yabancı ayrımı yapılmadığı görülmektedir. İkinci halde, Türkiye'de bulunma, ceza dâvası açılması için yeterlidir.

${ }^{45} 31$ Aralık 1960 tarihli ve 193 sayılı Gelir Vergisi Kanunu, Türkiye içinde ve dışında elde edilen kazancın vergilendirilmesinde esas olarak, "Türkiye'de yerleşik olma” kriterini aramaktadır. Tâbiiyet esasına dayanan, 5. maddede, yabancılar bakımından yerleşik sayılmama nedenleri belirtilmektedir. Türkiye'de yerleşik olmayanlar ise, sadece Türkiye'de elde ettikleri kazanç üzerinden vergilendirileceklerdir. Kanun'un tâbiiyet kriterine dayanan bir diğer hükmü de, 3. maddede yer almaktadır. Bu maddede, belirli görevlerle ülke dışında bulunan Türk vatandaşları tam mükellef olarak tanımlanmakta; ancak, yurt dışında ödenen vergilerin mahsubuna Gelir Vergisi Kanunu'nun 123. maddesiyle izin verilerek, mükerrer vergilendirme önlenmektedir. Bu açıdan bakıldığında, Vergi Hukuku bağlamında, vatandaş / yabanc1 değil; Türkiye'de yerleşik olma / olmama ölçütü önem arz ettiğinden, Vergi Hukukuna dayalı bir sınırlamanın, vatandaşlık değişimi üzerinde kural olarak, bir etkisi bulunmayacaktır. Bu konuda ayrıntılı bilgi için ayrıca bkz. : Muallâ ÖNCEL/Ahmet KUMRULU/Nami ÇAĞAN: Vergi Hukuku, B. 11, Ankara 2003, sh. 139 vd. ile, sh. 259 vd.
} 
tâbiiyet değişikliğinin etkisi bulunmayacaktır ${ }^{46}$ Ceza Hukuku bağlamında, vatana ihanet suçu gibi, Türk vatandaşı olma şartına bağlı suçlar bakımından da önemli olan, suçun işlendiği an olup; tâbiiyetin, suç teşkil eden fiilin tamamlanmasından sonra değişimi, yargılamanın yapılması veya mahkûmiyet kararının infazını engelleyici bir etkiyi haiz olamayacaktır. Ancak, ceza soruşturması, ceza dâvası açılması, hükmün infazının mümkün olmaması, Türk vatandaşlığından çıkmış kişinin, tâbiiyetini taşıdı̆̆ı yabancı devlet ülkesinden iadesinin talep edilebilmesini imkânsız kılabilir. ${ }^{47} \mathrm{Bu}$ açıdan bakıldığında, sadece, Türk vatandaşlığından çıkılarak Türk Devletinin vatandaşı üzerindeki kişisel yetkisinin sona erdirilmesi ve yabancı bir ülkede bulunması halinde, suçluların iadesi prosedürü içinde ülkeye iadesi talebinin mümkün olamaması; dolayısıyla, vatandaşın suç teşkil eden fiilinden dolayı yargılanması/ hükmün infaz edilmesinin imkânsız hale gelmesi ihtimali dikkate alındığında böyle bir düzenleme yerinde olabilir.

$\mathrm{Bu}$ kapsamda, ilgili kişilerin, vatandaşlıktan çıkmak suretiyle ve Türkiye'de haklarında ceza takibi yapılması ve hükmün infazı için öngörülen zamanaşımı sürelerini $^{48}$ ülke dışında geçirerek, TVK. md. 8 ve md. 29 hükmünden yararlanmaya devam edebilecekleri açıktır. ${ }^{49}$ Ancak, TVK. md. 8'den yararlanarak yeniden Türk vatandaşlı̆̆ının kazanımı, İçişleri Bakanlığı'nın takdir yetkisine tâbidir ve sözü edilen durum, bu aşamada değerlendirilebilecektir. TVK. md. 29 hükmünün sağladığı imkândan yararlanma ise, aslî yoldan Türk vatandaşlığını kazanmış iken Türk vatandaşlığından çıkma ve Türkiye Cumhuriyetinin millî güvenliği ve kamu düzenine ilişkin hükümler saklı kalma şartlarına bağlanmıştır. Türk vatandaşlığını çıkma suretiyle kaybetme, "müktesep tâbiiyetli" Türk vatandaşlarını da kapsayan, genel nitelikli bir maddedir. TVK. md. 29 ise, bazı eski Türk vatandaşlarını "özel statülü yabancı” kılan istisnâ̂ bir hükümdür. Dolayısıyla, herhangi bir suçtan aranma, cezaî tahdit bulunmama şartlarına, TVK. md. 20'de çıkma şartı olarak yer verilmektense,

\footnotetext{
${ }^{46}$ Türk Ceza Kanunu'nun yer itibariyle uygulanma alanı hakkında bilgi için bkz. : DÖNMEZER/ERMAN, age., sh. $254 \mathrm{vd;} \mathrm{CENTEL,} \mathrm{age.,} \mathrm{sh.} 80 \mathrm{vd.}$

${ }^{47}$ Nitekim, Türkiye'nin de tarafı olduğu 13 Aralık 1957 tarihli, Avrupa Konseyi Suçluların İadesine Dair Avrupa Sözleşmesi'nin 6. maddesi, üye devletlere vatandaşını iade etmeme yetkisi vermekte ve maddede vatandaşlığın tespitinde karar anı esas alınmakla birlikte, kişinin iade anına kadar, iade talep edilen devletin vatandaşlı̆̆ını kazanması halinde, iade talep olunan devlet iadeden kaçınabilmektedir. Mehmet AKZAMBAK : Lozan'dan Günümüze Taraf Olduğumuz Uluslararası Tüm Sözleşmeler, İnsan Hakları I, Ankara 1997, sh. 101 vd.

${ }^{48}$ Zamanaşımına tâbi olmayan suçlar hakkında bkz. : CENTEL, age., sh. 740.

${ }^{49}$ TVK. md. 26 kapsamında olarak, bazı suç türleri bakımından zaten çıkarma müessesesi de devreye girebilecektir.
} 
durumun TVK. md. 29'daki istisnaî imkândan yararlanabilme şartı olarak, bu maddede ele alınması daha uygun olurdu. ${ }^{50}$

6183 sayılı Amme Alacaklarının Tahsil Usûlü Hakkında Kanun'un 102. maddesinde öngörülen 5 yıllık tahsil zamanaşımının, aynı Kanun'un 104. maddesine göre, borçlunun ${ }^{51}$ yabancı ülkede bulunması nedeniyle hakkında takibat yapılmasına imkân yoksa, bu halin devamı müddetince işlemesini önleyecektir. Dolayısıyla, çıkma müessesinden yararlanarak Türk vatandaşlığından ayrılan eski Türk vatandaşı yabancı ile, ülke dışında bulunan Türk vatandaşları arasında bir fark yoktur ve bu açıdan bakıldığında da, vatandaş/yabancı sıfatının ayırt edici bir etkisi bulunmamaktadır.

Öte yandan, yabancı ülkede bulunulduğu sürece, zamanaşımı süresi işlemeyeceğinden, bu borçtan kurtulmak için Türk vatandaşlı̆̆ından çıkmak ve sonra TVK. md. 8'den yararlanarak Türk vatandaşlığını yeniden kazanmak yoluna başvurulmasının bir anlamı bulunmayacaktır. Benzeri şekilde, Gerekçe'de sözü edilen TVK. md. 29 da, Türk vatandaşlığından çıkan kişiye, malî mükellefiyetten kurtulma olanağı sağlamamaktadır. Sonuç olarak, malî sınırlamaların varlığı gerekçesiyle vatandaşlıktan çıkma talebinin reddi, sadece, vatandaşlıktan çıkmadan önce, tahakkuk eden borcun tahsilini sağlamaya yönelik "ek" bir zorlayıcı olanak yaratmış olmaktadır.

Eski Kanun maddesinde çıkma şartlarından biri olarak belirlenen, yabancı bir devlet vatandaşlığının kazanılmış olması veya kazanılacağına dair kuvvetli belirtiler bulunması sebebi, değişik madde hükmünde de aynen korunmuştur. Yabancı bir devlet vatandaşlığının kazanılacağına dair inandırıcı belirtiler bulunması şartının aranması, kullanılan ifadenin belirsiz olduğu ve çıma belgesinin yabancı bir devlet vatandaşlığı kazanılmadıkça zaten verilemeyeceği; bu nedenle de şartın aranmasının gereksiz olduğu; sözü edilen belirtilerle, uğraşmanın pratik bir yarar sağlamayacağ gerekçesi ile, doktrinde eleştirilmektedir. ${ }^{52}$

Esasen, çifte tâbiiyete imkân tanımayan ve bu nedenle halen taşınılan vatandaşlıktan çıkılmasına izin verildiğini gösteren bir belge olmadıkça, vatandaşlığa alınma başvurusunu reddeden bir devletin, vatandaşlığına yetkili makam kararıyla girmek, Türk vatandaşlığından çıkma, vatansız kalmama şartına bağlandığg sürece, mümkün olamayacaktır. Bu nedenle, çifte tâbiiyeti kural olarak reddeden ülke vatandaşlığının kazanımını

\footnotetext{
50 Yapılacak bir değişiklikte, TVK. md. 29'un mevcut düzenlemesi dahilinde, "millî güvenliğe ve kamu düzenine ilişkin hükümler saklı kalmak" ibaresi, sözü edilen somut hallerde, bu haktan yararlanmayı engelleyen bir içerikte yeniden kaleme alınabilir.

${ }^{51} 21$ Temmuz 1957 tarihli ve 6183 sayılı Kanun md. 3'de, borçlu terimi, "amme alacağını ödennek mecburiyetinde hakikî ve hükmî şahısları...yabancı şahıslar...'ı ifade eder", şeklinde tanırnlanmaktadır : RG. 28 Temmuz 1957, S. 8469.

${ }^{52}$ NOMER, age., sh.100; TURHAN, age., sh. 77; DOĞAN, agm., sh. 36; DOĞAN, age., sh. 121.
} 
sağlayabilmek ve özellikle yaşadıkları/çalıştıkları yabancı ülkelerde daha geniş haklardan yararlanabilmek amacıyla, bir anlamda zorunlu olarak tâbiiyet değiştirecek olan Türk vatandaşlarının, uğrayabileceği hak kaybını önleyebilmek için, henüz yabancı bir devlet vatandaşlığını kazanamamış kişilere de, çıkma izninin verilmesine imkân sağlayan bir düzenlemenin varlığ1 uygundur. Ancak, bu ikinci halde, çıkma izninin, Yönetmelik'te öngörüldüğü biçimde inandırıcı belirti şartına bağlanması, kanımızca eleştiriye açıktır.

Zira, hukuka saygılı idare ilkesi gereği, uygulamada yeknesaklı̆̆ı sağlayacak şekilde, Yönetmelik'in 31. maddesiyle somutlaştırılmış bulunulan bu soyut ifade kapsamında, yetkili organın dikkate alacağı inandırıcı belirtiler, "ilgilinin vatandaşlığına geçmek istediği devlet makamlarınca verilmiş o devlet vatandaşlığına kabul edileceğine dair bir belge; ilgilinin Türk vatandaşı olarak o ülkede uzun zamandan beri oturmasına ve orada meslekî, ticarî veya sınaî faaliyetlerde bulunmasına izin verildiğini gösteren belge; veya o devlet vatandaşı ile evli olması ve bu durumun vatandaşlığa alınmasında kolaylıklar sağlayacağının anlaşılmış olmasıdır". Çıkma iznini, verecek makamın bu belirtiler sayesinde, yabancı bir devlet vatandaşlı̆̆ını kazanma ihtimali bulunmayan bir başvuru değerlendirmesi yaparak zaman kaybına uğrama riskinden kurtulacağ düşünülse bile, maddede sözü edilen belirtiler, bu işlevi yerine getirmekten uzak kalmaktadır. Nitekim, maddede zikredilen belirtilerin "sınırlı sayıda olduğu"nu gösterir biçimde kaleme alınmış olması nedeniyle ${ }^{53}$, bunun dışında bir yolla -örneğin yabancı bir devlet vatandaşıyla evlilik benzeri bir birliktelik sürdürme ${ }^{54}$ ve bunun vatandaşlı̆ga alınmada kolaylık sağlayacak bir neden olarak nitelendiriliyor olması-yabancı bir devlet vatandaşlığının kazanılabilme ihtimalinin ispatı, olanaksız hale gelmektedir; ayrıca, ilgilinin bir ülkede uzun süre oturması ve meslekî, ticarî faaliyetlerde bulunulmasına izin verilmesinin inandırıcı delil vasfı taşıması, bu durumun ilgili ülke hukukunca vatandaşlığa alınmayı kolaylaştıran bir neden olarak düzenlenmiş bulunmasına bağlıdır. Yoksa, Yönetmelik'te belirlenen bu halin tek başına, yabancı bir devlet vatandaşlığına alınmayı kolaylaştıran bir neden yaratması mümkün değildir. Öte yandan, bu belirtilerin, çıkma izninin süresince de ortaya çıkması ya da sona ermesi olasıdır.

Tüm bu nedenlerle, TVK. md. 20'de yapılacak bir değişiklikle, çıkma kararı verilebilmesini5 "başvuru anında, yabancı bir devlet vatandaşlığının

\footnotetext{
${ }^{53}$ Aksi yönde, DOĞAN, age., sh. 120.

${ }^{54}$ Nitekim, bu tür evlilik benzeri ilişki modelleri, bazı hukuk sistemlerinde kabul görmüş ve hukukî bir düzenlemeye kavuşturulmuş bulunmaktadır. Bu ülkeler için bkz.: Fügen SARGIN: "Yetişkinlerin Milletlerarası Plânda Korunmasına Dair La Haye Sözleşmesi”, AÜHF., 2003, C. 52, S. 2, sh. 6 .

${ }^{55}$ İzin ve çıkma belgesinin, İçişleri Bakanlığı'nın çıkma izni üzerine verileceği açıktır. Eski düzenlemede, bu ayrım, çıkma iznini verecek makam, Bakanlar Kurulu olduğu için daha açık
} 
kazanılmış ya da yabancı bir devlet vatandaşlığının kazanılması için müracaat edilmiş ve müracaat edilen devletin yetkili makamlarınca, vatandaşlığın kazanılacağına dair bir güvence verilmiş olması" şartıyla mümkün kılan ${ }^{56}$, bir ibareye yer verilmesinin, tüm bu eleştirileri gidermek bağlamında yerinde olacağ düşünülmektedir. ${ }^{57}$

Buna paralel biçimde, Kanun maddesinin, "başvuru anında yabancı bir devlet vatandaşlığını taşıyanlara, TVK. md. 20'de aranan şartlar dahilinde, İçişleri Bakanlığı'nca çıkma kararı verileceği; çıkma kararının ilgiliye tebliğ ile hüküm ifade edeceği; başvuru anında henüz bir yabancı devlet vatandaşı olmayanlar hakkında ise, TVK. md. 20'de belirlenen şartların varlığının/yokluğunun tespiti koşuluyla, İçişleri Bakanlığı'nca, 3 yıllık bir süre içinde yabancı bir devlet vatandaşlı̆̆ının kazanılması şartına ve süresine bağlı olarak çıkma kararı alınacağı ve 3 yıllık sürenin sonunda yabancı bir devlet vatandaşlığı kazanılamamışsa, bu kararın kendiliğinden hükümsüz ${ }^{58}$

biçimde görülebilmekte idi. Çıkma izni ve belgeleri verecek makamı, İçişleri Bakanlığı olarak belirlemek suretiyle yeni düzenlemenin, artık çıkma izni aranmaksızın, TVK. md. 20'de öngörülen olumlu/olumsuz şartları taşıyan/taşımayan kişilere takdire bağlı olarak hazırlanan izin ve çıkma belgelerinin doğrudan verileceği sonucunu yaratan bir lâfzı ve içeriği bulunmamaktadır. Zira, TVK. md. 20 çerçevesinde verilecek çıkma izni, yetkili makamın takdirine bağlı iken; TVK. md. 22'ye göre çıkma izni üzerine verilecek belgeler bakımından böyle bir takdirî yetki bulunmamaktadır.

${ }^{56}$ Benzeri hüküm için bkz.: Staatsangehörigkeitsgesetz ( StAG), §. 18.

${ }^{57}$ Avrupa Vatandaşlık Sözleşmesi'nin 8. maddesinde, vatandaşlığın iradî kaybı için üye devletlere yapacakları düzenlemeler bağlamında getirilen sınırlamalardan biri, "vatansız kalmamak"; diğeri de, isteğe bağlı olarak "ülkede ikamet etmiyor olmak" şartlarıdır. Ancak, Sözleşme'nin 29. maddesi çerçevesinde, üye devletlerin bu maddeye çekince koyma hakları bulunmaktadır. Yine, vatansızlık hallerinin önlenmesini ya da azaltılabilmesini sağlamak amacıyla Türkiye'nin tarafı olmadığı, 18. maddesi uyarınca 13 Aralık 1975'de yürürlüğe giren ve 26 ülke tarafından onaylanmış bulunulan Vatansızlığın Azaltılması Hakkında 30 Ağustos 1961 tarihli Birleşmiş Milletler Sözleşmesi "UN. Convention on the Reduction of Statelessness", nin 7. maddesi hükmü de, vatandaşlıktan çıkmayı, ilgilinin halen yabancı bir devlet vatandaşı bulunması ya da yabancı bir devlet vatandaşlığını kazanıyor olmasıı şartına bağlamış bulunmaktadır. Bkz.: http://www.unhchr.ch/html/menu3/b10_reduce.htm (14 Ocak 2004 itibariyle); Ayrica bkz.: UN, Treaty Series, Vol. 989, sh. 175.

${ }^{58}$ Esasen, belli bir süreye veya şarta bağlanmış idarî kararlar, bu sürenin dolması ya da şartın gerçekleşmemesi halinde idarenin ayrıca bir karar almasına gerek olmaksızın kendiliğinden ortadan kalkacaktır. Bkz.: Metin GÜNDAY: İdare Hukuku, B. 8, Ankara 2003, sh. 164; Ancak, çıkma izninin yabancı bir devlet vatandaşığ̆ını kazanamamış kişi hakkında nasıl bir hüküm ifade edeceği yönünde doktrinde ortaya çıan tereddütlere son verebilmek için, bu ibarenin metin içinde zikredilmesine gerek vardır. Zira, doktrinde ifade edildiği üzere, "̧̧ıkmada verilen izin tarihinden itibaren 3 yıl içinde çıkma belgesi alınamamış ise, vatandaşlığın kaybı kesinleşir. Bu bekleme süresi, Türk vatandaşlığından çıkan şahsın tâbiiyetsiz kalmaması için yeni bir tâbiiyet kazanmasına fırsat tanımak maksadıyla konulmuştur. Bu müddet içinde tâbiiyet alınamadığı takdirde, şahıs tâbiiyet değiştirmede serbest olmalıdır prensibinin tahakkukuna imkân verilmiştir”: Osman Fazıl BERKI: 
hale geleceğ $\mathrm{i}^{59}$; yabancı devlet vatandaşlı̆̆ını kazanma anına kadar TVK. md. 20'de öngörülen şartlar doğduğu veya ortadan kalktığı için, çıkma kararı yetkili makam tarafından kaldırılmıs olmadıkça, ilgililerin bildirimi kaydıyla $^{60}$, yabancı devlet vatandaşlığının kazanıldığı anda, Türk vatandaşlığının, kaybedilmiş sayılacağı; yabancı devlet vatandaşlığının kazanıldığının, ilgili ya da vatandaşı olunan yabancı devletçe bildirimi üzerine, yetkili Türk makamlarınca yapılacak tespitin ve düzenlenecek belgenin kurucu değil bildirici nitelik taşıyacağı"nı yansıtacak biçimde kaleme alınması, sübjektif kamu hakkı tanımı dahilinde uygunluk arz edecektir.

İkinci halde, Türk vatandaşlığının kaybı anının, yabancı bir devlet vatandaşlığının kazanıldığı an olarak tayin edilmesi, mevcut düzenleme çerçevesinde ortaya çıkabilecek sakıncaları gidermek bakımından da yerinde olacaktır. Nitekim, mevcut TVK. md. 23'e göre, vatandaşlık, başvuru sahibinin gerekli bilgi ve belgeleri teslimi üzerine düzenlenecek çıkma belgesinin imza karşıllı̆̆ verildiği an (Yönetmelik md. 33) kaybedilmektedir. Yabancı devlet vatandaşlığının kazanımı anı ile, çıkma belgesinin verildiği an arasında geçecek sürede, TVK. md. 20'de öngörülen olumsuz şartlardan biri gerçekleşirse, örneğin bir vergi borcu doğarsa, verilen çıkma izni hukuka aykırı hale gelecek ve bu kararın yetkili makam tarafından kaldırılması gerekecektir. Çıkma belgesi verilmesinin dayandığı hukukî sebep de, hukuka uygun biçimde verilmiş bir çıkma izninin varlığıdır. Çıkma izni verildikten sonra, vatandaşlığın kaybı anına kadar TVK. md. 20'de öngörülen şartlar, somut başvuru bağlamında değişirse, hukuka aykırı hale geleceğinden, bu izne dayalı olarak verilecek bir çıkma belgesi de, hukuka aykırı sayılacaktır. Dolayısıyla, yetkili makam, çıkma belgesi düzenlerken, TVK. md.20'de belirlenen şartların devam edip etmediğini ya da bulunmadığını göz önüne almak zorundadır. Böyle bir tespit halinde, çıkma izni kaldırılacağından çıkma belgesi verilmesi mümkün olamayacaktır. Kaldırma anına kadar, hukuka uygun bir izinle elde edilmiş bir yabancı vatandaşlık söz konusu olacak; kişi çifte tâbiiyetli sıfatı kazanacaktır. Bu durum, Türk Hukuku açısından bakıldığında, TVK. md. 25/(a) anlamında bir irade dışı kayba yol açmayacak olsa da, vatandaşlık kazanımında çifte tâbiiyeti kabul etmeyen ülkeler bakımından, bir irade dıșı kayıp hali yaratabilecektir. Böylece, henüz yabancı bir devlet vatandaşı̆̆ı̆ı kazanamamış kişilere, çıkma başvurusunda

Devletler Hususî Hukuku, C. I, “Tâbiiyet ve Yabancılar Hukuku”, B. 6, Ankara 1966, sh. 111.

${ }^{59}$ Bu halde, TVK. md. $23 / 2$ ve Yönetmelik md. 34/4'e dayanılarak, kaybettirme kararı, artık verilemeyecektir.

60 Yabancı devlet vatandaşlığının kazanımı üzerine, süresi içinde ilgilinin gerekli bilgi ve belgeleri Türk makamlarına vermekten kaçınması, mevcut TVK. md. 23/2 hükmü gereğince vatandaşlı̆̆ın kaybettirilmesi nedeni sayıldığı için, bu durum bir kaybettirme nedeni olmaktan çıkarılmadıkça, ilgilinin Türk makamlarına bildirimi önem arz edecektir. 
bulunma imkânı veren TVK. md. 20 hükmüyle güdülen amaçla uyumsuz bir sonuç ortaya çıkacaktır.

\section{2. Çıkma İzni Verecek Yetkili Makamın ve Kullanacağı Yetkinin Niteliğinin Tespiti}

Türk vatandaşlı̆̆ından çıkma iznini verecek olan makam, yeni düzenlemeye göre, artık Bakanlar Kurulu değil; İçişleri Bakanlığı'dır. Bu suretle, çıkma izni işlemlerinin, daha hızlı ve daha sade bir prosedür izlenerek, kolaylaştırılması ve mağduriyetlerin önlenmesi amaçlanmaktadır. ${ }^{61}$

İlgili Bakanlık'ın, Kanun'da öngörülen şartlar gerçekleşmiş olsa bile bireyin talebini reddedebilme yetkisi bulunmaktadır. İlgili Bakanlık'a konu bakımından bir takdir yetkisi tanınmış olduğu, 3. maddenin 1 . f 1 krasında kullanılan “çıkma izni, aşağıdaki şartların varlığı halinde, İçişleri Bakanlığı tarafından verilebilir", ifadesinden anlaşılmaktadır.

Vatandaşlığın yetkili makam kararı ile kaybında, idarî işlemin sebep unsuru içinde açıkça yer almak suretiyle, "savaş gibi olağanüstü hallerde haklılık kazanacak ulusal menfaatlere aykırı olma" sebebi hariç ${ }^{62}$; kural olarak, idareye bu tür bir takdir yetkisinin tanınmamış olması ve çıkma talebi üzerine, kanunda öngörülen şartları taşıyan birey hakkında çıkma izni verilmesi konusunda bağlı yetkinin bulunması; yani, çıkma talebinin, sübjektif bir kamu hakkı olarak nitelendirilerek, "herkesin vatandaşlığını seçme ve değiştirmede özgür olması gerektiği" ya da "kimseye zorla tâbiiyet yükletilemeyeceği" yönündeki tâbiiyetin direktif ilkesine, başka bir ifadeyle, çıkma müessesinin temelinde yatan düşünceye ${ }^{63}$ uygun bir düzenleme getirilmesi yerinde olurdu. Bu açıdan bakıldığında, Kanun'da belirtilen olumlu/olumsuz şartları taşıyan/taşımayan talep sahibinin, artık vatandaşlık bağını devam ettirmek istemediği bir ülkeye buna rağmen bağlı kalmasını sağlamanın mantıklı bir nedeni bulunmamaktadır.

İçişleri Bakanlığı'na verilen bu yetki nedeniyle, doğumla Türk vatandaşlığını kazanmış olup da, çıkma kararıyla vatandaşlıktan ayrılmış

\footnotetext{
${ }^{61}$ Bkz. Dn. (37)'de, TVK. md. 8'de yapılan değişiklikle ilgili olarak yapılan açıklamalar.

${ }^{62}$ ABD. Hukukunda, Immigration and Nationality Act Title III, Chapter 3, Section 349 / (a) / 5 ve 6 'ya göre sırasıyla, aslen veya mükteseben $A B D$. vatandaşlı̆̆ını kazanmış olan herkes, $\mathrm{ABD}$. dişında bir yabancı ülkede, $\mathrm{ABD}$. konsolosluğu veya diplomatik temsilciliği önünde Dışişleri Bakanlığı tarafından tayin edilen format dahilinde, kendi isteğiyle resmî olarak feragat ettiği veya ABD.'de ise, Adalet Bakanlığı tarafından belirlenen şekilde ve bu makam tarafından tayin edilen yetkili organlar önünde yazılı biçimde resmî fẹragatta bulunduğu takdirde, $\mathrm{ABD}$. vatandaşh durumuyla sınırlı olarak, Adalet Bakanlı̆̆ı'nın, böyle bir vatandaşlıktan ayrılmanın, millî savunma menfaatlerine aykirı olmadığını onaylamış olması zorunludur. Bkz. http://www.immigration-usa. Com / ina _96_title_3.html (12 Aralık 2003 tarihi itibariyle). ${ }^{63}$ GÖĞER, age., sh. 129; TURHAN, age., sh. 68.
} 
bireylerin saklı tutulan haklarını düzenleyen TVK.'nun 29. maddesinde yer alan "Bakanlar Kurulu" ifadesi de, doğal olarak "İçişleri Bakanlığı" biçiminde değiştirilmiştir.

\section{Vatandaşlıktan Çıkmanın Çocuklar Üzerindeki Etkisi}

TVK.'nun 32. maddesinde yapılan değişikle, "küçük" olan çocukların, istisnaen Türk vatandaşlığından çıkma kararıyla ayrılan anne veya babalarını takip etmelerinin şartları yeniden düzenlenmiş bulunmaktadır. Eski kanun maddesi ile karşılaştırıldığında, yapılan tek aslî değişikliğin, çocuğun velâyet hakkı olan ana veya babayı takip ederek vatandaşlıktan ayrılabilmesi için, velâyet hakkı olmayan ebeveynin rızasının; bu rıza yoksa, mahkemenin izninin aranmasından ibaret olduğu görülmektedir. ${ }^{64}$

$\mathrm{Bu}$ madde ile ilgili olarak yapılması gereken ilk eleştiri, TVK.'nun 32. maddesinin eski metninde yer alan, alternatif şartların, değişik Kanun hükmü ile de aynen korunmuş olmasıdır. Çocuğun anneyi takip etmesi şartları arasında yer alan "babanın belli olmaması", "ananın belli olmaması" şeklinde, küçük çocuğun babayı takip etmesi şartlarından biri olarak belirlenmemiştir. Bu ayrıma gidilmesinde etken olan düşünce, Türk Hukuku'na göre, annenin onu doğuran kadın olması ve doğumla anneyle çocuk arasında hukukî bir nesep ilişkisinin kurulmasıdır. Ancak, annenin yabancı olduğu hallerde, nesep ilişkisinin, tâbi olacağı yetkili yabancı hukuk, anne ile çocuk arasındaki nesep ilişkisini, baba ile olduğu gibi aynı şekilde düzenlemiş olabilir. Bu nedenle, söz konusu alternatif şart bağlamında bu ayrımın yapılmış olması yerinde değildir. ${ }^{65}$

\footnotetext{
${ }^{64}$ Bunun dışında, TVK. md. 32'nin eski metninde yer alan, “ Ananın Türk vatandaşlığından çıkması küçük çocuğun vatandaşlı̆̆ına tesir etmez. Ancak..." ibaresi de, artık yeni TVK. md. 32 metninde yer almamaktadır.

${ }^{65}$ Vatandaşlık kazanma ya da kayıp halleri ile sınırlı olarak, ön sorun teşkil eden evlilik, nesep, fiil ehliyetinin varlığı, küçük olma gibi sorunlann, Türk Hukuku'na göre belirlenmesi gerektiği; zira bunun devlete vatandaşlık bağı ile bağlı bireyleri tesbite yönelik Kamu Hukukuna ait bir keyfiyet olduğu düşünülebilir. Bunun dışında söz konusu sorunların, kanunlar ihtilâfı kuralları aracılığı ile belirlenen yetkili hukukun maddî hükümleri esas alınarak çözülmesi gerektiği sonucuna da varılabilir. Konuya TVK. hükümleri çerçevesinde bakıldığında, kanun koyucunun, istisnaî olarak bazı maddelerinde uygulanacak hukuka dair açıklamalara yer verdiği görülmektedir. Nitekim, yetkili makam kararı ile vatandaşlık kazanımında aranan reşit olma şartını, ilgilinin millî hukuku; vatansız ise Türk Hukuku'na tâbi kılan TVK. md. 6; seçme hakkını kullanarak Türk vatandaşlığını kazanacak yabancıların, Türk Medenî Kanunu'na göre reşit olmalanını arayan TVK. md. 12 bu istisnaî duruma ömek teşkil edebilir. Dolayısıyla, bu hükümlerden hareketle, TVK. bakımından kanun koyucunın tercihini belirlemek mümkün gözükmemektedir. Ancak kanımızca, hì halde, kăıusiar ihtilâf kurallarına başvuru daha uygun gözükmekıedir. Zìn, üis sorun teşkil eden bu hukukî

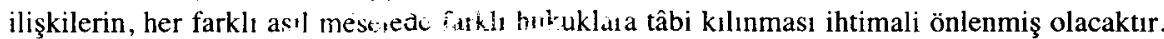
Bu çerçevede, kanuniar ihtilâfı huhuku kurallarının gösterdiği yetkili hukuka göre kurulduğu tespit oujicn hi- .esep ilişkisi, tâbiiyet hukuku dışında, nesebin ön sorun teşkil ettiği diğer miineue de tek bir hukuka göre var ya da yok sayılacaktır.
} 
Değişik 32. maddenin eleştiriye açık bir diğer yönü de, çocuğun tâbiiyet değişiminde, "velâyet hakkının varlığı"nın, aslî şart olarak öngörülmemiş olmasıdır. Velâyetin anada/babada olması, başlı başına ayrı bir alternatif şart sayılmaktadır. Nitekim, örneğin, küçük çocuğun anneyi takip ederek Türk vatandaşlığından ayrılması için, babanın ölmüş veya belli olmaması ya da yabancı sıfatını taşıması yeterli olup; velâyetin ayrıca annede olması gerekrnemektedir.

Oysa, çocuğun, Türk vatandaşlığından ayrılan annesini takip etmesi için öngörülen alternatif şartlar dikkate alındığında, çocuğun anneyi takip etmesi, baba ille arasındaki bağın zayıf ya da hiç bulunmamasına (ölüm, belli olmama, velâyetin anada bulunması) veya Türk vatandaşlığından ayrılacak annenin yanı sıra, babanın da zaten yabancı olması nedeniyle, Türkiye ile olan bağın zayıflayacak olması düşüncesine dayanmaktadır. Hal böyle iken, velâyetin annede bulunmadı̆̆ı hallerde, çocuğun aralarındaki zayıf bağa rağmen, babanın ölmüş, belli değil veya yabancı olması şartlarından birinin gerçekleşmesi nedeniyle anneyi takip etmesi ve bu suretle, Türk vatanclaşlığını kaybedecek olması, maddede temel alınan düşünce dahilinde anlaş1lır gibi değildir. Başka bir ifade ile, çocuğun anneyi takip etmesi için, babanın ölmüş, belli değil ya da yabancı olması yeterli olup; çocuk ile anne arasında velâyet ilişkisinin doğurduğu yakın bir bağın varlığı aranmamaktadır. Dolayısıyla, annesi ile arasında, nesep bağı dışında yakın bir ilişkisi kalmayan ve Türkiye'yle bağı başka nedenlere dayalı olarak devam eden çocuğun, Türk vatandaşlığını buna rağmen kaybedecek olması mantıklı değildir. Esasen, böyle bir durumda, devreye girecek vesayet dairesinin $^{66}$, sözü edilen hususları, çocuğun menfaati kriteri dahilinde bir değerlendirmeye tâbi tutacağı; bu nedenle, söz konusu eleştirinin etkisiz kalacağı ifade edilebilir. Ancak, kanımızca, çocuğun menfaatini tespit etmek üzere devreye girecek vesayet idaresinin de, küçüğüun, kendisinden velâyet hakkı alınmış ebeveynini izleyerek Türk vatandaşlığından ayrılmasına izin vermesinin, özellikle de velâyetin nez'i nedenleri dikkate alındığında, zaten pratikte pek de mümkün olamayacağı düşünülmektedir. Öte yandan, bu düşünce doğrultusunda, çocuğun velâyet hakkına sahip olmayan ebeveyne dayanarak yabancı bir devlet vatandaşlığını kazanması da, zayıf bir ihtimal gözükmektedir. Aynı eleştiri, Türk vatandaşlığını babaya bağlı olarak kaybedecek küçük çocuklar için de varittir. Bu nedenlerle, çocuğun Türk vatandaşlığından çıkan anne ve/veya babayı izlemesi, velâyet hakkının

\footnotetext{
${ }^{66}$ TVK. md. 32'deki mevcut düzenlemeye göre, küçük çocuğun vatandaşlıktan çıkan anne veya babayı takip edebilmesi, aralarında bir velâyet ilişkisinin varlı̆̆ını zorunlu kılmadığından, Türk Hukuku'na göre (TMK. md. 404 ve MÖHUK. md. 9 ), vesayet altına alınmış küçük çocukların, Türk vatandaşlığından çıkma talebinde bulunan ve velâyet hakkı bulunmayan anne ve/veya babalarını takip etmeleri mümkündür ve bu halde de, TMK. md $463 / 2$ uyannca, vesayet organlarının izni, bir şart olarak aranacaktır.
} 
varlığı şartına bağlanmalı; tıpkı küçük olma şartı gibi aslî nitelik kazanmalıdır.

Daha öncede ifade edildiği üzere, Kanun'un ilgili maddesinde yapılan tek yenilik, ana veya babaya bağlı olarak küçük çocuğun vatandaşlığını kayıp şartı olarak düzenlenen, velâyetin anada bulunması veya velâyetin babada bulunması halinde, velâyet hakkı olmayan anne veya babanın yazılı izninin alınması; bu iznin alınamadı̆̆ hallerde ise, mahkemeye müracaat edilecek bulunulmasıdır. Gerekçe'de, çocuk üzerinde ebeveynlerinin birlikte tasarrufta bulunmalarının sağlanarak, iki tarafın rızasının olmadığ 1 bir tasarrufun sakıncalarının ortadan kaldırılmasının amaçlandığı zikredilmektedir. ${ }^{67}$ Oysa, bu aşamada önem ve öncelik arz eden husus, kanımızca, çocuğun vatandaşlığı üzerinde ebeveynlerin ortak rızalarının varlığından ziyade, somut şartlar dahilinde Türk vatandaşlığını kaybın, küçüğün lehine bir durum yaratacağının saptanması olmalıydı. Bu nedenle, TVK. md. 32'de, genel çerçevede Türk vatandaşlığının kaybının aslî şartlarından biri olarak, doğrudan küçüğün menfaatini saptayan bir mahkeme kararının verilmesini öngören bir hükme yer verilmesi daha uygun düşerdi.

Öte yandan, çocuğun menfaatine uygun biçimde bu kararı verecek yargı organının hangi mahkeme olacağı da, TVK.'nda belirtilmemektedir. Doktrinde, bir görüş, TMK.'nun 397. ve 411. maddelerinden hareketle, bir sonuca varmaktadır. Buna göre, "vesayet işlerinde yetki, küçügün veya kısıtlının yerleşim yerindeki vesayet dairelerine aittir". Vesayet makamı, sulh hukuk; denetim makamı, asliye hukuk mahkemesidir. ${ }^{68} \mathrm{Bu}$ konuda doktrinde yer alan diğer bir görüş ise, görevli ve yetkili mahkemeyi, HUMK.'da düzenlenmiş genel yetki kuralı çerçevesinde, dâvalının yerleşim yeri asliye hukuk mahkemesi olarak belirlemektedir. Görüşe göre, ilgili mahkeme, çocuğun vatandaşlı̆̆ının değişmesini, TMK.'nun 183. maddesinde öngörülmüş olan, yeni olayların ortaya çıkması, kapsamında değerlendirerek karar verecektir. ${ }^{69}$

Ancak, kanımızca TMK.'nun 397. ve 411. maddelerinden hareketle, TVK. md. 32'de sözü edilen mahkemelerin tespiti mümkün değildir. Bir kere, ilgili TMK. hükümleri, velâyete değil; vesayet kurumuna ilişkindir; ayrıca, TMK'nda belirlenen vesayet makamı da mevcut hükümler dahilinde

\footnotetext{
${ }^{67}$ TVK. md. 32'de öngörülen ebeveynin yazılı muvafakının alınması gereğinin dayandırıldı $\breve{1}$ gerekçe şudur: “..Madde ile 15 yaşından küçük çocuklarda, velâyete sahip olmayan ana veya babanın, 15 yaşından büyük çocuklarda ise, çocuğun bu konuda muvafakatının alınması koşulu getirilerek, çocukların vatandaşlığı üzerinde ebeveynin birlikte tasarrufta bulunması ilkesi kabul edilmektedir. Bununla iki tarafın rızasının olmadığı bir tasarrufun sakıncalarının ortadan kaldırılması amaçlanmıştır." Gerekçe için bkz. : http://www.tbmm gov.tr/sirasayi/ donem22/yil01/ss115m.htm

${ }^{68}$ AYBAY, age., sh. 155.

${ }^{69}$ DOĞAN, age., sh. 132.
} 
aile mahkemeleri olarak anlaşılmak durumundadır. ${ }^{70} 09$ Ocak 2003 tarihli ve 4787 sayılı Aile Mahkemelerinin Kuruluş, Görev ve Yargılama Usûlüne Dair Kanun'un 7. maddesine göre ${ }^{71}$, vesayet makamı olarak aile mahkemesince verilen kararlara karşı, TMK.'nun 397. maddesinde belirlenen denetim makamı görevi, varsa bir sonraki numaralı aile mahkemesince, yoksa o yerdeki asliye hukuk mahkemesince, bu derecede bir mahkeme yoksa, en yakın yerdeki aile mahkemesi veya 2. maddenin 2 . fıkrasına göre görevlendirilen asliye hukuk mahkemesince yerine getirilecektir. $^{72}$

TVK.'nun 32. maddesinde ifade edilen mahkemelerin, aile mahkemeleri olarak anlaşılabilmesi için, 4787 sayılı Kanun'un 4. maddesine göre, uyuşmazlığın Türk Medenî Kanunu'nun İkinci Kitabı ile Türk Medenî Kanunu'nun Yürürlüğü ve Uygulama Şekli Hakkında Kanun'a göre Aile Hukukundan doğan dâva ve işlerle ilgili olması veya kanunlarla özel yetki verilmiş bulunması gerekir. Bu çerçevede, çocuğun vatandaşlık değişimine izin verecek görevli mahkemenin tespitinde, TMK.'nun 183. maddesinden yararlanmak mümkün gözükmemektedir. Zira, bu madde, boşanma ve ayrılık kararı verilirken mahkemece belirlenen velâyet hakkı ve velâyet hakkı bulunmayan ebeveynle çocuk arasında kurulan kişisel ilişkinin, yeni olguların zorunlu kılması üzerine, değişen duruma uygun biçimde yeniden düzenlenmesini hükme bağlamakta ve hâkime bu yönde önlem alma görevi yüklemektedir. Oysa, TVK. md. 32'de sözü edilen izin, velâyet hakkının değişimine ya da yeniden düzenlenmesine yol açmayan; sadece velâyet hakkı olmayan ebeveynin rızası yerine geçecek bir onayı yansıtmaktadır.

\footnotetext{
${ }^{70}$ Bununla birlikte, vesayet işlerinin aile mahkemelerinin görev alanından çıkarılması hususunda bir kanun tasarısı, Başbakanlık tarafından Adalet Komisyonu'na gönderilmiş bulunmaktadır. Tasarı'nın 1. maddesine göre, 4787 sayılı Kanun'un 4. maddesinin (1) no.'lu bendine,"Türk Medenî Kanunu’nun", ibaresinden sonra gelecek şekilde, "Üçüncü Kısım hariç olmak üzere" ibaresi eklenmiştir. Sözü edilen değişikliği içeren "Aile Mahkemelerinin Kuruluş, Görev ve Yargılama Usûllerine Dair Kanunda Değişiklik Yapılmasına İlişkin Kanun Tasarısı”nın gerekçesi şöyledir: “....Türk Medenî Kanunu'nun vesayet başlıklı Üçüncü Kısmında, kayyımlık, yasal danışmanlık, koruma amacıyla özgürlüğün kısıtlanması, değerli şeylerin saklanması, paralanı yatırılması, ticarî ve sınaî işletmelerin işletilmesi veya tasfiyesi ve taşınmaz malların satılması gibi doğrudan Aile Hukukunu ilgilendirmeyen konular yer almakta olup; bu konular niteliği itibariyle, ayrı bir uzmanlık gerektirmekte ve Aile Hukukundan çok genel hukuku ilgilendirmektedir......Bu itibarla, aile mahkemelerinin kuruluş amacına uygun olarak görev alanının yeniden belirlenerek vesayet konusuna istisna getirilmesi ve bu hükme paralel biçimde, aile mahkemelerinin vesayet ve denetim makamı olarak görev yapmalarını sağlayan anılan Kanun'un 7. maddesinin 2. fıkrasının yürürlükten kaldırılması amacıyla bu Tasarı hazırlanmıştır". ( 27 Şubat 2004 tarihi itibariyle). Tasarı kanunlaştığı takdirde, vesayet ve denetim makamı yine, Türk Medenî Kanunu'nun 463/2. maddesi uyarınca sulh ve asliye hukuk mahkemeleri olacaktır.

${ }^{71}$ RG. 18 Ocak 2003, S. 24997.

${ }^{72} 4787$ sayll Kanun'un 2. maddesine göre, aile mahkemeleri, asliye hukuk mahkemeleri derecesinde olmak üzere kurulur.
} 
Başka bir ifade ile, TVK. md. 32 gereğince yetkili k1lınan hâkim, vereceği kararla, çocuğun Türk vatandaşlığını kaybetmesine izin vermektedir. Bu izni verirken hâkimin yapması gereken, Türk vatandaşlığından ayrılmanın "çocuğun menfaati"ne uygun olup olmadığını belirlemektir. Bu açıdan bakıldı ğında, "çocuğun menfaatinin tehlikeye düştüğü hallerde", hâkime önlem alma yetkisi veren Türk Medenî Kanunu'nun 346. maddesinin kıyasen uygulanabileceği sonucuna varılabilecektir. Dolayısıyla, bu durum, TMK.'nun velâyeti düzenleyen (İkinci Kitap, İkinci Kısım, Birinci Bölüm, Altıncı Ayırım) hükümleri dahilinde, "çocuğun korunması" başlığı altında bir Aile Hukuku sorunu olarak nitelendirilebilecektir. Buna bağlı biçimde, söz konusu görevli mahkemenin, aile mahkemeleri olacağı açıktır. Aynı gerekçe, görevli mahkemenin HUMK.'nun görev kurallarına dayanılarak tespitini de önlemektedir.

Bununla birlikte, ilgili maddede yapılacak bir değişiklikle, bu hususun, hangi mahkemenin görev alanına girdiğini gösteren açık bir ifadeye yer verilmesi daha uygun olacaktır.

Eski TVK. md. 32'de yer alan ve bu suretle, Türk vatandaşlığından ayrılacak küçük çocukların vatansız kalmayacak olmaları şartını zorunlu kılan hükmü ise, yeni Kanun maddesinde yerinde olarak aynen korunmuştur. $^{73}$

TVK. md. 32 hükmüyle ilgili olarak yukarıda yapılan saptamalar ışı̆̆ında, maddenin bu karmaşık uygulamasına son verecek yeni bir düzenlemeyle, çocukların Türk vatandaşlığından çıkma kararıyla ayrılan anne ve/veya babalarını takip etmeleri, şu şartlara bağlanmalıdır: küçük olma; çocuğun velâyet hakkı olan ebeveyni takip etmesi; yabancı devletin, anne ve/veya babanın yanı sıra, çocuğu da bu yolla vatandaşlığına alıyor olması; aile mahkemelerinin "küçüğün menfaati"nin varlığını tespit eden karar1.

\section{SONUÇ}

1. TVK.'da çeşitli tarihlerde yapılan değişiklikler ile birbirleriyle olan mantıksal bütünlüğünü ve dolayısıyla temelinde yatan bütünleştirici felsefeyi kaybetmiş hükümlerden oluşan bir maddeler manzumesi haline gelen mevcut Kanun'umuz, tümüyle yeni bir düzenleme yapılması gereğini gündeme getirmiştir. Yapılan son değişiklikler ile de maddeler arasındaki uyumsuzluk daha bir belirginlik kazanmış bulunmaktadır. ${ }^{74}$

7330 Ağustos 1961 tarihli Birleşmiş Milletler Vatansızlığın Azaltılması Hakkında Sözleşme'nin 6. maddesi aynı yönde bir hüküm içermektedir.

${ }^{74} \mathrm{Bu}$ bağlamda, daha önceki yıllarda yapılan değişikliklere sadece bir kaç ömek teşkil etmek üzere, özellikle 10. madde zikredilebilir. Madde ile getirilen şartlı vatandaşlık kazanma imkânı, vatandaşlığın objektif, genel kanun hükümleri ile önceden belirlenmesi ve sürekliliğini gerekli kılan 1982 tarihli Anayasa'nın 66. maddesiyle belirlenmiş "kanunilik" ilkesine aykırılık yaratmaktadır. İdarenin takdirine bağlı olarak her somut başvuruda farklı 
2. Genel çerçevede bakıldığında, 1982 tarihli Anayasa'mızın 66. maddesinde Türk vatandaşlığının, "milliyet"ten arındırılmış "hukukî bir tanım"ının yapılmış ve "kanunilik ilkesi"ne bağlanmış olması; doğumla vatandaşlık kazanımında kadın ve erkek arasında yaratılan eşitsizliği kaldıran ve bu suretle Anayasa'nın 10. maddesinde ifadesini bulan "eşitlik ilkesi"ne uygunluğu sağlayan Anayasa md. 66 değişikliği; Kanun'un vatansızlığı önlemek amacıyla getirdiği pek çok hükmün varlığı; irade dı̧ı kayıp hallerinde, Türk vatandaşlığına geri dönmeyi ya da yeniden Türk vatandaşlı̆̆ını kazanmayı imkân dahiline sokan kurallara yer verilmesi; Vatandaşlık Hukuku alanında, özellikle irade dışı kayıp halleri bakımından öngörülen Anayasal yargı güvencesi gibi hususlar göz önüne alındığında, Türk Vatandaşlık Hukuku kurallarının, temel insan hakları bağlamında övgüye değer bir yeri olduğu açıktır. Ancak, mevcut Kanun'da yer alan bazı maddelerin, Anayasa'mızın 10. maddesine aykırı biçimde kadın/erkek eşitliğine dayanmadığı da bir gerçektir. Erkeğin üstünlüğünü esas alan ailede

biçimde belirlenebilecek vatandaşlığa alınma şartları, kanunla düzenleme prensibini zedelemektedir. Aynı yönde bkz. DOĞAN, age., sh. 105; Yine, 13 Şubat 1981 tarihli ve 2383 sayılı Kanun'la, TVK.'na eklenen ve çifte tâbiiyet kazanma imkânını düzenleyen bir hüküm, vatandaşlıktan çıkma müessesi içinde sistematiği bozan bir görünümde yer almaktadır. Öte yandan, 22. maddenin 2 . fıkrasında, bu imkân açıkça sadece henüz bir yabancı devlet vatandaşlığını kazanamamış Türk vatandaşlarına tanınmış iken, geniş yoruma tâbi tutularak madde, izinsiz olarak kendi istekleri ile yabancı bir devlet vatandaşlı̆̆ını kazanmış kişileri de kapsar hale getirilmiş ve üstelik yayımlanmayan bir Yönetmelik hükmü ile bu yorum tarzı işlerlik kazanmıştır. Her ne kadar, Türk vatandaşlarının kaybettirme müeyyidesi ile karşılaşmalanın önlemek amacından hareketle genişletici yorum yapmanın uygun olacağı düşünülebilirse de, Anayasa'nın 66. maddesi gereği vatandaşlık kanunla kazanılıp kaybedileceği için, bu hükümlerin dar yorumlanması esastır. Dolayısıyla, Kanun maddesi, hakkında düzenleme getirmediği kişileri de içine alacak şekilde geniş yorumlanamaz ve bir yönetmelik hükmü ile Kanun'da düzenlenmemiş bir konuda, vatandaşlığın kaybı ya da kazanılmasına dair hüküm getirilemez. Kanun'un izinsiz yabancı vatandaşlık kazanmış kişilere imkân tanımadı̆̆ını gösteren diğer bir ifade de, 22. maddenin son fıkrasında yer almaktadır. Nitekim, md. 22/son fıkrada, henüz bir devlet vatandaşlığını kazanamamış kişilere 3 yil için geçerli bir izin belgesi verileceği ifade edilmektedir. Daha önce vatandaşlı̆̆ kazanmış bir bireye, 3 yıl için geçerli bir belge vermenin mantığı yoktur. Nitekim, Yönetmelik'in yayımlanmamış değişik 32. maddesinde bu durum göz önüne alınarak, Kanun'a açıkça aykırı biçimde, “....izin almadan yabancı bir devlet vatandaşlığına geçmiş olup da bu durumlarının tespitinden önce başvurarak Türk vatandaşlı̆̆ını da koruma izni isteyen kişilerin başvuracakları makamlar'dan söz edilmekte; “....söz konusu işlemler için müracaat edenlere, Nüfus ve Vatandaşlık İşleri Genel Müdürlüğüi'nce düzenlenen ve Kanun'un 20. maddesi uyarınca Türk vatandaşlı̆̆ından çıkma izni için (form A), 22. madde uyarınca başka bir devlet vatandaşlı̆̆ına geçme izni için (form B), izin almadan başka bir devlet vatandaşlığına geçmiş olup da Türk vatandaşlığını koruma izni için (form $C$ ) olarak düzenlenmiş bir form doldurtulacağı" ifade edilmiş bulunmaktadır. Yönetmelik hükmü için bkz.: Vahit DOĞAN: Milletlerarası Özel Hukuk Mevzuatı, B. 2, Ankara 2002, sh. 130; Aksi yönde görüş için bkz. : DOĞAN, age., sh. 124-126; NOMER, age., sh. 103-104. 
tâbiiyet birliğini sağlama prensibinin hâkimiyeti altında düzenlenen maddeler ile, bu düşüncenin sonucu olarak kimi zaman kadını korumaya yönelik hükümler içeren 403 sayılı TVK., modern Vatandaşlık Hukuku duizenlemelerinde ve insan haklarına dair temel metinlerde ifadesini bulan, kadın erkek eşitliğine dayalı söylemleri ${ }^{75}$ yansıtmaktan uzaktır. ${ }^{76}$ Son değişiklikler, dikkat çekici ölçüde, bu eşitsizliğin örneklerini çoğaltmış bulunmaktadir.

3. Nihaî olarak yapılması gereken, Milletlerarası Hukukun izin verdiği ölçüde, çağdaş Vatandaşlık Hukuku düzenlemelerinde belirginleşen genel eğilimi ortaya koyan metinleri de mümkün olduğunca dikkate alarak, devletsel menfaatler doğrultusunda ortaya çıkacak politik tercih dahilinde, Türk devletine vatandaşlık bağı ile bağlanacak kişilerin tayini hususunun yeniden ele alınmasıdır. Bu bağlamda, tarafı olunulması düşünülen Avrupa Vatandaşlık Sözleşmesi hükümleri de özel bir önem arz etmektedir.

4. 4866 sayılı Kanun ile getirilen değişikliklerle sınırlı olarak, ileride hazırlanması muhtemel bir tasarıda göz önüne alınmak üzere yapılacak bazı öneriler ise şunlardır:

a. Özellikle, TVK. md. 5'in eski düzenlemesi ile bütünlük arz eden Kanun maddeleri, değişik TVK. md. 5 hükmüne göre, yeniden ele alınmalıdır. Bu çerçevede, evlenme suretiyle vatandaşlık kazanımı, kolaylaştırıcı telsik nedenlerinden biri olarak, "yetkili makam kararı ile Türk vatandaşlığının kazanılması" başlığı altında düzenlenmeli; bu suretle, doktrinde ortaya çıkan görüş ayrılıkları ile uygulamada yaratacă̆ kaçınılmaz sorunun giderilmesi sağlanmalıdır. Bununla bağlantılı biçimde, kolaylaştırıcı telsiki düzenleyen 7 . maddenin yeniden gözden geçirilmesi ${ }^{77}$ ve bir Türk vatandaşı ile evli olanlar ${ }^{78}$ ya da evlenme kararıyla Türkiye'ye yerleşenlerin bu yolla vatandaşlık kazanımı imkânına son verilmesi en uygunu olacaktır.

Evlenme suretiyle vatandaşlığın kazanımında, yabancı eşin, evliliğin belirli bir süresinde, örneğin 18 ay, Türkiye'de ikamet etmesi; Türk vatandaşı eşin, kendi iradesiyle yabancı ülkede ikamet etmesi durumunda, 3

\footnotetext{
${ }^{75}$ Avrupa Vatandaşlık Sözleşmesi md. 5'e göre, taraf devletlerden hiç birinin tâbiiyete ait kuralları; cinsiyet, din, ırk, renk ya da ulusal veya etnik köken açısından ayrımcılık oluşturan farklılıklar ya da herhangi bir uygulama içeremez.

${ }^{76}$ Nitekim, TVK. md. 14, 15, 16, 17, 19, 27/a hemen bu kapsamda zikredilebilecek hükümlerdir; kadınlar lehine getirilmiş TVK. md. 16 dışında, Türk Vatandaşlık Hukukunda tam bir eşitliğin bulunduğu yönünde aksi görüş için bkz. NOMER, age., sh. 47-48.

77 TVK. md. 7'nin belli bir süre Türkiye'de ikamet etme şartı aramayan hükmü de değiştirilmelidir. Bu süre, olağan telsik için aranandan daha kısa ve bazı hallerde bu şarttan muafiyete imkân veren bir takdirî yetki, yetkili makama tanınmak suretiyle belirlenebilir.

${ }^{78}$ Benzeri gerekçeyle, KKTC. Yurttaşlık Yasası'nın 9. maddesinde, bu sebebin istisnaî vatandaşlığa alınma nedenleri arasında sayılmadığı yönünde görüş için bkz. TURHAN, age., sh. 56.
} 
yıldan daha uzun bir süre evlilik birliğinin devamı ile, Türkiye'yle yakın ilişkisini gösteren evlilik dışında kalan başka nedenlerle de desteklenme şartımın aranması ve yabancı ülkede Türkiye'yi temsilen görev yapan Türk vatandaşlarının yabancı eşleri bakımından Türkiye'de ikamet etme şartından sarfınazar edilmesi, yapılabilecek yeni bir düzenlemede dikkate alınabilecek hususlar olarak zikredilebilecektir.

İkamet süresinin tamamlanması kaydı ile, evliliğin butlan/iptal/ölüm/ boşanma nedenleri ile sona ermesi halinde, Türkiye ile yakın bağı ortaya koyacak diğer ölçütler ışı̆̆ında, evlenme suretiyle yabancı eşe vatandaşlık kazanımı imkânı da tanınmalıdır.

Öte yandan, evlenme suretiyle vatandaşlık kazanımında, başvuru sahibi yabancı eşin Türk yaşam tarzına uyum sağlamış ve vatandaşlığa alınmasının Türkiye'nin iç ve dış güvenlik, devletlerarası ilişkileri hususundaki menfaatlerine aykırılık yaratmaması şartları da, bir vatandaşlığa alınma sebebi olarak düzenlenmelidir. ${ }^{79}$

Evlenme nedeniyle Türk vatandaşlı̆̆ına alınmada, makûl ölçülerde sona erdirmenin beklenemeyecek olması ya da mümkün bulunmaması hali hariç ${ }^{80}$, eşin mevcut vatandaşlığına son vermesi ve eşi takip edecek önceki küçük çocukların Türk vatandaşlığını kazanımının, eski vatandaşlığını yitiriyor olmaları şartına bağlanması düşüncesi ise, hazırlanacak yeni bir kanunun tümüne egemen olacak "çifte tâbiiyet”e yönelik, Devletin takındığı genel tavır çerçevesinde somutlaşabilecektir.

b. TVK. md. 8 hükmünün kapsamının, çıkarma hariç tüm kayıp hallerini kapsayacak şekilde genişletilmesi; yeniden vatandaşlığa alınabilecek kişilerin, "sadece eski Türk vatandaşı olmaları dışında", vatandaşlı̆̆ın kaybından sonra kurulmuş ve Türkiye ile güncel/gerçek bir bağı gösterecek şekilde olağan yoldan yetkili makam kararıyla Türk vatandaşlığına alınacak kişilere nazaran belirlenecek daha kısa sürelerle Türkiye'de ikamet etmeleri şartının getirilmesi de, "etkin vatandaşlık" ilkesinin kabulüne bağlı olarak düşünülmesi gereken hususlardan biri olarak dile getirilebilir. TVK. md. 8 hükmünün, çifte tâbiiyete izin vermeyen çalıştıkları/yaşadıkları ülkedeki hukukî durumlarını iyileştirmek amacıyla, Türk vatandaşlığından çıkma talebinde bulunmak suretiyle ayrılarak, bu ülke vatandaşlığını kazanmış ve halen bu ülkelerde ikamet etmekte olan eski Türk vatandaşları bakımından, şartlar elverdiğinde, Türk vatandaşlığına geri dönmelerinde bir kolaylık sağladığı açıktır. TVK. md. 6 gereğince, bu kişilerin, Türkiye'ye yerleşmeye karar verdiğini gösterecek bir karine olarak Türkiye'de taşınmaz mal sahibi olması, ülkeye sermaye aktarımı yapması, bir Türk vatandaşı ile evlenmesi yeterlidir ( Yönetmelik md. 10/(c) ). İkamet

\footnotetext{
${ }^{79} \mathrm{Bu}$ yönde bir düzenleme için bkz. Staatsangehörigkeitsgesetz ( StAG), §.9/(1)/2.

${ }^{80}$ Karş. Staatsangehörigkeitsgesetz ( StAG), §. 9/(1)/1 ve Avrupa Vatandaşlık Sözleşmesi, md. 15 ve md. 16; Alman Hukuku için ayrıca bkz. HOFFMANN, agm., sh. 150.
} 
şartının aranması, bu kişilerin yeniden Türk vatandaşlığına alınmalarını önleyecektir. Bu kişiler, TVK. md. 29 gereğince, zaten, tıpkı Türk vatandaşları gibi haklardan yararlanmaya devam etmektedirler. Ancak, bu kişilerin Türk vatandaşlığına alınma başvurusunda bulunmaları, halen vatandaşı oldukları ülkelerin Vatandaşlık Hukuku kuralları çifte tâbiiyete izin vermedikçe, mevcut vatandaşlığın irade dışı kaybına yol açabileceğinden, pratikte pek de mümkün olmayacaktır. Dolayısıyla, yeniden vatandaşlığa alınmada bu şartın aranması makûl gözükmektedir. Yine de, bu kişilerle sınırlı olarak, yetkili makama, ikamet şartından istisna etmek yetkisi de verilebilir. Bu konuda söylenmesi gereken son husus, yeniden vatandaşlığa alınmanın ikamet şartına bağlanmasının, TVK. md. 7 'de de benzeri bir değişiklik yapılması halinde anlam ifade edeceğidir.

c. Türk vatandaşlığından çıkma talebinde bulunmanın, "kişi tâbiiyetini değiştirmede özgür olmalıdır" direktif ilkesi doğrultusunda yeniden ele alınarak, vatansız kalmamak (başvuru anında çifte tâbiiyetli olmak ya da vatandaşlığa alınma başvurusunda bulunduğu devlet tarafından verilen bir güvence sahibi bulunmak) ve Türkiye'de ikamet etmemek şartları dişında bir sınırlamaya tâbi tutulmaksızın ve sübjektif bir kamu hakkı olarak nitelendirilerek, idarenin takdir hakkını kaldıran bir düzenlemeye kavuşturulması uygun olacaktır. Bununla birlikte, olağanüstü dönemlerde, ulusal güvenlik açısından sakınca bulunan hallerin mevcut olması ihtimali dahilinde, yetkili makama, bu durumu göz önüne alabileceği istisnaî bir yetki de tanınabilmelidir.

Bu çerçevede, şahsa sıkı sıkıya bağlı haklardan biri olduğu için ${ }^{81}$, reşit ama tam ehliyetsiz kişilerin, kanunî temsilcileri aracılığıyla dahi, Türk vatandaşlığından çıkamayacakları düşüncesi de, yeni bir düzenleme yapılması aşamasında gözden geçirilmelidir. Nitekim, kanımızca tam ehliyetsizlere de, kanunî temsilcilerinin talebi üzerine, "bireyin yararı kriteri"ne bağlı olarak, aile mahkemelerinin vereceği bir karar ile ${ }^{82}$, Türk vatandaşlığından çıkma izni verilmesi imkânı düşünülmelidir. Ancak bu halde, reşit ancak, temyiz kudreti olmayan ve henüz yabancı bir devlet vatandaşlığını kazanamamış Türk vatandaşlarının, Mukayeseli Hukuk verilerine göre tespit edilecek kanunî temsilcileri aracılığı ile, vatandaşlığa alınma başvurusunda bulunup bulunamayacakları hususu da, çıkma hakkının tanınmasında rol oynayacaktır. ${ }^{83}$

\footnotetext{
${ }^{81}$ Vatandaşlığı, şahsa sıkı sıkıya bağı hak olarak tanımlayan mahkeme kararlan için bkz.: BERKI/ANSAY/ARAT, age., sh. 180-181; Ayrica bkz. D.10.D., T. 14 Nisan 1987, E. 86/1906, K. 87/769.

${ }^{82}$ Vesayet altında bulunan reşit Türk vatandaşlan bakımından bir sorun yoktur. Türk Medenî Kanunu'nun 463. maddest, vesayet makamının izniyle, vatandaşlıktan çıkılabileceğini öngö̀thektedir.

8313 Ocak 2000 tarihli Yetişkinlerin Milletlerarası Plânda Korunmasına Dair Sözleşme'ye dair Açıklayıcı Rapor'da bu durum, ehliyetsiz yetişkinin yetkili makam kararı ile
} 
Küçük çocukların velâyet hakkı bulunmayan ebeveynlerini takip ederek iradeleri dışında Türk vatandaşlığını kaybetmelerinin önlenmesi ve hem velâyetin sadece anne veya babaya ait olduğu; hem de bu hakkın ortak paylaşıldığı durumlarda, küçük çocukların Türk vatandaşlığını kaybetmelerinin, velâyet hakkı olan anne ve/veya babayı takip ediyor olmaları; anne ve/veya babaya vatandaşlık veren yabancı devlet hukukuna göre bu nedenle vatandaşlık kazanıyor bulunmaları ve aile mahkemesinden "menfaat"in varlığını tayin eden bir karar alınması, şartlarına bağlanması hususları da, TVK.'nun 32. maddesinde gerçekleştirilebilecek bir değişiklik bağlamında yapılabilecek önerilerdir.

5. Buna paralel olarak, TVK.'nda yapılan çoğu değişikliği yansıtmayan ya da yayımlanmayan yönetmelikler ile değişikliğe uğratılan Yönetmelik de, bir an önce, hiç değilse mevcut değişikliklere uygun biçimde yeniden düzenlenmeli ve kamuyu ilgilendiren, dolayısıyla aleniyet gerektiren düzenleyici işlemler olması nedeniyle mutlaka yayımlanarak Kanun'un uygulanmasını kolaylaştıran bir düzenleyici işlem haline yeniden dönüştürülmelidir. 


\section{KAYNAKÇA}

AKZAMBAK, Mehmet: Lozan'dan Günümüze Taraf Olduğumuz Uluslararası Tüm Sözleşmeler, İnsan Hakları I, Ankara 1997.

AYBAY, Rona: Vatandaşlık Hukuku, B. 5, İstanbul 2003.

AYBAY, Rona: "Türk Vatandaşlı̆ı̆ı Kanunu'nda Geri Gidiş Getiren Değişiklik", Açı Sayfa, 2003, S. 45-46, sh. 20-22.

BERKİ, Osman Fazıl: Devletler Hususî Hukuku, C. I, "Tâbiiyet ve Yabancilar Hukuku", B. 6, Ankara 1966.

BERKİ, Osman Fazıl / ANSAY, Tuğrul / ARAT, Tuğrul: Devletler Hususî Hukuku ile İlgili Danıştay ve Yargıtay Kararları, C. I (Tâbiiyet Hukuku), Ankara 1975.

CENTEL, Nur: Türk Ceza Hukukuna Giriş, B. 2, İstanbul 2002.

ÇİÇEK, Amir: Vatandaşlık ve Yabancılar Hukuku Alanında GelişmelerBilimsel Toplant1, İstanbul 24-25 Eylül 1998, İstanbul 2000, sh. 83- 90 .

DOĞAN, Vahit: "Vatandaşık Kanununun Bazı Maddelerinin Değiştirilmesine İlişkin Kanun Tasarısı Çerçevesinde Bir Değerlendirme", Gazi Üniversitesi Hukuk Fakültesi Dergisi, 1999, C. III, S.1-2, sh. 25-45.

DOĞAN, Vahit: Türk Vatandaşlık Hukuku, B. 3, Ankara 2003.

DÖNMEZER, Sulhi / ERMAN, Sahir: Nazarî ve Tatbikî Ceza Hukuku, Genel Kısım, C. I, B. 13, İstanbul 1997.

GÖĞER, Erdoğan: Türk Tâbiiyet Hukuku, B. 4, Ankara 1979.

GÜNDAY, Metin : İdare Hukuku, B. 8, Ankara 2003.

GÜNDÜZ, Aslan: Milletlerarası Hukuk Metinleri, B. 4, İstanbul 2000.

HOFFMANN, Rainer: "German Citizenship Law and European Citizenship: Towards a Special Kind of Dual Nationality" in European Citizenship (Ed. By Massimo La TORRE), The Hague/London/Boston 1998, pp. 149-165.

NOMER, Ergin: Vatandaşılk Hukuku, B. 13, İstanbul 2002.

SARGIN, Fügen: "Yetişkinlerin Milletlerarası Plânda Korunmasına Dair La Haye Sözleşmesi", AÜHF., 2003, C. 52, S. 2, sh. 1- 75 .

ÖNCEL, Muallâ/KUMRULU, Ahmet/ÇAĞAN, Nami: Vergi Hukuku, B. 11, Ankara 2003.

TURHAN, Turgut: Kuzey Kıbrıs Türk Cumhuriyeti Yurttaşlık Hukuku, Ankara 2002.

Avrupa İnsan Hakları Sözleşmesi, Ankara 1998, Turhan Kitabevi Yayınları. 